\title{
Hydrological cycle of the Mediterranean-Black Sea system
}

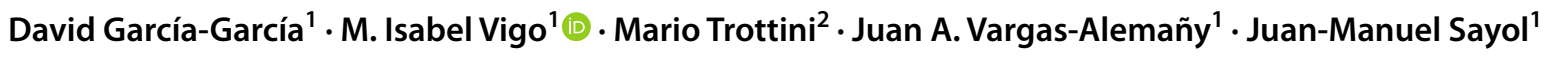

Received: 30 July 2021 / Accepted: 2 February 2022 / Published online: 22 February 2022

(c) The Author(s) 2022

\begin{abstract}
The Mediterranean-Black Sea system consists of two semi-enclosed basins connected by the Turkish Straits. In turn, the Mediterranean Sea is connected to the Atlantic Ocean through the narrow Strait of Gibraltar. The hydrological cycle of the system is driven by fresh water exchanges between the atmosphere, continents and oceans, and by salty water mass exchange among the ocean basins. Monitoring such water fluxes, especially its time evolution, is essential to understand the water cycle in the region, which is very sensitive to global climate changes and influences the variability of the Atlantic Meridional Overturning Circulation (AMOC), which in turn affects the global climate. In this study, we have estimated the hydrological cycle of the Mediterranean-Black Sea system from the time-variable gravity observations performed by the Gravity Recovery and Climate Experiment (GRACE) and GRACE Follow-On satellites, and precipitation and evaporation from ERA5 atmospheric reanalysis data for the period 2002-2020. In the Black Sea, rivers introduce an average water volume of $391 \pm 12 \mathrm{~km}^{3} /$ year, one third of which escape through the atmosphere and two thirds go to the Mediterranean Sea. In the latter, $1787 \pm 23 \mathrm{~km}^{3} /$ year are lost via net evaporation. The rivers runoff $\left(502 \pm 27 \mathrm{~km}^{3} /\right.$ year $)$, and the inflow of Atlantic waters $\left(1020 \pm 56 \mathrm{~km}^{3} /\right.$ year; $\left.0.0323 \pm 0.0018 \mathrm{~Sv}\right)$, finally restore the Mediterranean water budget. The balance is not reached instantaneously, and this delay introduces a seasonal variability in all the fluxes. In particular, the net water flux from the Atlantic Ocean increases up to $2660 \pm 111 \mathrm{~km}^{3} /$ year in August/September, and reverses to $-407 \pm 140 \mathrm{~km}^{3} /$ year in April/ May. On top of the climatology, the mean annual Atlantic water flux varies significantly between 706 and $1262 \mathrm{~km}^{3} /$ year.
\end{abstract}

Keywords Water transport $\cdot$ Mediterranean-Black Sea system $\cdot$ Satellite gravimetry $\cdot$ Runoff $\cdot$ Strait of Gibraltar $\cdot$ Turkish straits

\section{Introduction}

The global water cycle is expected to intensify due to global warming (Held and Soden 2006; Huntington 2006; Greve et al. 2014), and such intensification is already taking place (Durack et al. 2012; Markonis et al. 2019; Pascolini-Campbell et al. 2021). In this context, the Mediterranean-Black Sea system has been identified as one of the most important responsive regions to climate change (Giorgi 2006). On the other hand, the flux of warm and salty water from the Mediterranean Sea to the Atlantic Ocean influences the variability of the Atlantic Meridional Overturning Circulation (AMOC;

M. Isabel Vigo

vigo@ua.es

1 Department of Applied Mathematics, EPS, University of Alicante, 03690 San Vicente del Raspeig, Alicante, Spain

2 Department of Mathematics, Faculty of Sciences, University of Alicante, 03690 San Vicente del Raspeig, Alicante, Spain
Reid 1979; Artale et al. 2006; Pérez-Asensio et al. 2012). Among other tracers, the AMOC distributes heat within the Earth system and influences temperature and precipitation patterns worldwide (Vellinga and Wood 2002), and it is expected to weaken in the twenty-first century leading to profound climatic and ecological changes over vast regions (Collins et al. 2019). For these reasons, it is critical to monitor the hydrological cycle in the Mediterranean-Black Sea system, as well as its temporal variability, not only due to its important influence in the ecologic and socio-economic conditions of such a densely populated area, but also because it can be useful to gain new insights into global climate change.

The Mediterranean Sea is a semi-enclosed sea of $2.5 \times 10^{6}$ $\mathrm{km}^{2}$, where evaporation $(E)$ exceeds precipitation $(P)$, and the deficit of water mass must be replenished by horizontal water fluxes, namely, continental fresh waters input, and salty waters inflow from the Atlantic Ocean and Black Sea. The connection with the Atlantic takes place through the 
Strait of Gibraltar (14 km at the narrowest point and $300 \mathrm{~m}$ depth at the shallowest one), and with the Black Sea through the Turkish Straits. The Dardanelles Strait is $62 \mathrm{~km}$ in length, between 1.2 and $7 \mathrm{~km}$ in width, $55 \mathrm{~m}$ in mean depth, and connects the Mediterranean Sea to the Sea of Marmara. The latter is connected to the Black Sea through the Bosphorus Strait, which is nearly $31 \mathrm{~km}$ in length, between 0.7 and $3.5 \mathrm{~km}$ in width, and $35 \mathrm{~m}$ in mean depth. Thus, the Mediterranean Sea water budget equation can be written as

$d W=P-E+R+G+T$,

where $d W$ is the change of water content; $R$ consists of river runoff, ice melting, and submarine groundwater discharges into the ocean; $G$ and $T$ are the net water mass fluxes through the Gibraltar and Turkish Straits, respectively, whose positive (negative) values are considered as Mediterranean inflows (outflows).

The Black Sea is another semi-enclosed basin, but with $0.44 \times 10^{6} \mathrm{~km}^{2}$, that is less than a fifth of the Mediterranean Sea extension. Here, the water budget equation is simpler, since salty water can only be exchanged through the Turkish Straits. Therefore, the Black Sea water budget equation is obtained from Eq. 1 by setting $G=0$. Here, positive (negative) values of $T$ are considered as Black Sea inflows (outflows).

In the continents, the drainage basins discharging into the Mediterranean and Black seas are defined according to the global continental runoff pathways scheme (Oki and Sud 1998), and they cover $5.34 \times 10^{6}$ and $2.43 \times 10^{6} \mathrm{~km}^{2}$, respectively (Fig. 1). In the Mediterranean Sea, the area of the continental drainage basin doubles the oceanic area, while the former quintuples the latter in the Black Sea. In both cases, the water budget equation can be applied by cancelling the salty water inputs in Eq. 1, that is setting $G=0$ and $T=0$, and replacing " $+R$ " by " $-R$ ". Knowing $P, E$, and $d W$ in a continental drainage, the corresponding $R$ can be estimated as a residual in Eq. 1.

The general picture of the Mediterranean-Black Sea system is as follows. Net precipitation in the catchment regions flows to the sea after a time-variable period of residence. In both Mediterranean and Black seas, $E$ exceeds $P$, which contributes to a net loss of water vertically. In the Black Sea, the continental inflow not only replenishes such loss, but produces a surplus of water that is transported superficially to the Mediterranean Sea. At the same time, near the bottom saltier Mediterranean waters go into the Black Sea. Altogether these fluxes accumulate a net water mass transport from the Black Sea to the Mediterranean Sea of $0.0087 \pm 0.0019 \mathrm{~Sv}\left(275 \pm 59 \mathrm{~km}^{3} /\right.$ year $)$, as reported in a literature revision by Jordà et al. (2017).

In the Mediterranean Sea the situation is different since continental inflow is not sufficient to replenish the water

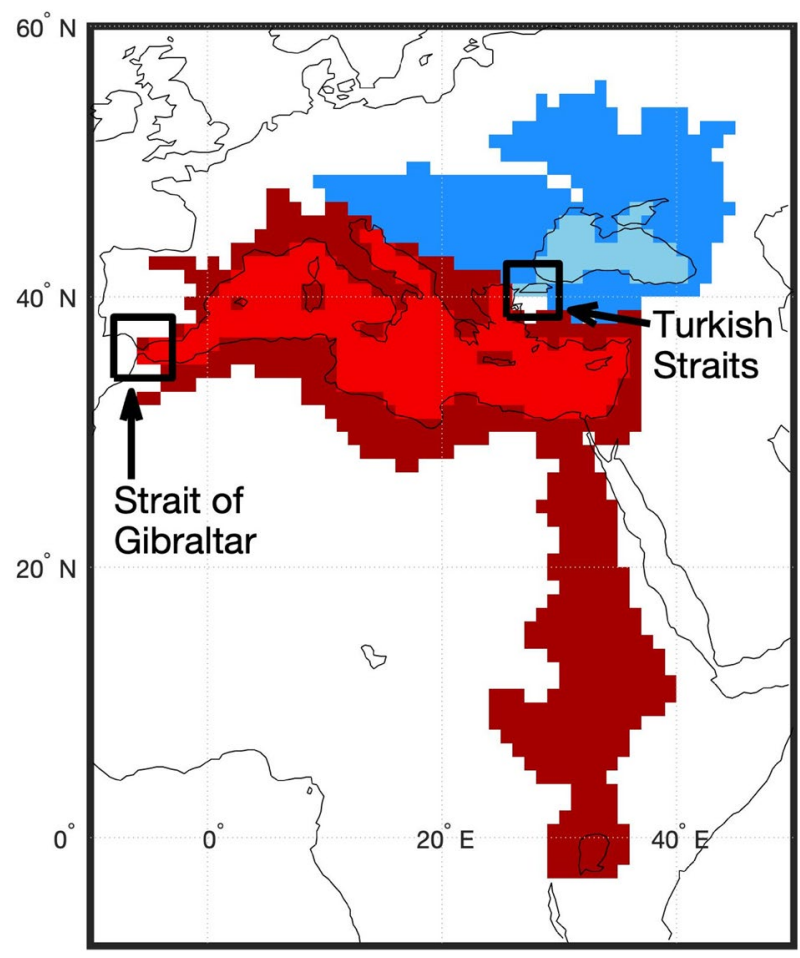

Fig. 1 Mediterranean-Black Sea system. Light red: Mediterranean Sea; dark red: continental basins draining to the Mediterranean Sea; Light blue: Black Sea; dark blue: continental basins draining to the Black Sea. The locations of both Strait of Gibraltar and Turkish Straits are indicated by black rectangles

mass lost via net evaporation. When the contribution from the Black Sea is accounted for, net evaporation is not yet balanced, and an inflow of Atlantic waters is needed to keep the Mediterranean water budget. The Atlantic waters get saltier and denser in the Mediterranean Sea due to the excess of evaporation (which also explains the higher salinity in the Mediterranean Sea). In this sense, the Mediterranean Sea is considered an inverse estuary or concentration basin that increases water density and stimulates deep water formation. As a consequence of the increase in density, Atlantic waters, once in the Mediterranean Sea, sink forming the Levantine Intermediate Water (LIW) in the Rhodes Gyre region, the Eastern Mediterranean Deep Water (EMDW) in the Adriatic Sea, and the Western Mediterranean Deep Water (WMDW) in the Lions Gyre (for further information on Mediterranean Sea circulation we refer the reader to Millot and TaupierLetage 2005; Bergamasco and Malanotte-Rizzoli 2010). This more saline nutrient-rich water is transported to the Atlantic Ocean through the Strait of Gibraltar below the less dense and nutrient-poor input from the Atlantic (McGill 1953; Coste et al. 1988; Gómez et al. 2000). Altogether, the Mediterranean Sea receives a net inflow of $0.065 \pm 0.033 \mathrm{~Sv}$ $\left(2050 \pm 1041 \mathrm{~km}^{3} /\right.$ year) from the Atlantic Ocean as reported in a literature revision by Jordà et al. (2017). 
In this work we apply the recent method developed by García-García et al. (2020) to track water flux changes in the Mediterranean-Black Sea system. This knowledge provides new insights on the seasonal and inter-annual water mass exchanges between continents and oceans, and between the oceans themselves. Additionally, these results represent a new source of data based on observations potentially useful to validate oceanic and atmospheric models, as well as other type of observations, especially in geographically complex straits such as the Gibraltar or the Turkish Straits.

The article is organized as follows. Data and methods are described in Sect. 2. Section 3 analyzes the water transport (WT) components in terms of mean values, seasonal and non-seasonal variability, and the influence of the North Atlantic Oscillation (NAO) in them. Discussion of results and conclusions are presented in Sect. 4.

\section{Data and methods}

\subsection{Data}

Net precipitation, $P-E$, is obtained from ERA5 reanalysis (Hersbach et al. 2018), which assimilates observational data into general-circulation modelling provided by the European Centre for Medium-Range Weather Forecasts (ECMWF). It has a global coverage of both continents and oceans at monthly (and hourly) intervals. Data are $0.25^{\circ}$ regular grids for years 2002-2020. Grids have been homogenized to $1^{\circ} \times 1^{\circ}$ to match the spatial resolution of the continental drainage basin data.

Water mass budget variations, $d W$, are estimated from the RL06 GRACE mascon (mass concentration) v2 solution provided by the Center of Space Research of University of Texas (Save et al. 2016; Save 2019) for the period May 2002-October 2020, with missing values between the end of GRACE mission and the beginning of GRACE Follow-On, that is from July 2017 to May 2018. Besides, the values of 12 single months and 5 pairs of consecutive months were missing and have been linearly interpolated. Data are on a $0.25^{\circ}$ regular grid, but we have re-gridded them to $1^{\circ}$ regular grids as we did for $P-E$. Note that the obtained spatial resolution is still finer than the $\sim 300 \mathrm{~km}\left(\sim 3^{\circ}\right.$ near the Equator $)$ resolution of GRACE, which measures gravity anomalies from month to month with respect to a dynamic geophysical model that accounts for solid and ocean tides, among other factors. Assuming that the gravity changes are produced by mass changes on Earth's surface, such as in the oceans, the mascon solution can be interpreted as water mass $(W)$ budget anomalies (Chao 2016). Time variations of $W$ (that is $d W$ ) are estimated as the discrete central derivative of $W$, $d W(t)=\frac{d W(t+1)-d W(t-1)}{2}$,

where $t$ refers to any given month. As a result, $d W$ data span from June 2002 to June 2017 and from June 2018 to September 2020. The same months are selected for $P-E$ data.

Usual corrections are applied to GRACE data: $\mathrm{C}_{20}$ coefficient was replaced by a solution from Satellite Laser Ranging (Cheng and Ries 2017), $\mathrm{C}_{30}$ coefficient was also replaced in GRACE Follow-On data, estimates for degree-1 coefficients were used (Swenson et al. 2008; Sun et al. 2016), a correction of glacial isostatic adjustment was applied (GIA) (Peltier et al. 2018), and the GAD product, which accounts for non-tidal variations of the atmosphere and ocean, was added back with the mean value of the ocean set to zero. The latter is done for consistency with the treatment of the Stokes coefficients anomalies of degree-0, $\Delta \mathrm{C}_{00}$, which account for variations of the total mass of the Earth. Including the atmosphere, the total mass of the Earth is constant, and then $\Delta \mathrm{C}_{00}$ are null. Excluding the atmosphere, the mass of the Earth is not constant since there is an exchange of water-mass between the surface and the atmosphere at a global scale, and in that case $\Delta \mathrm{C}_{00}$ are not null. During GRACE processing, atmospheric and dynamic oceanic mass changes are removed, and $\Delta \mathrm{C}_{00}$ are set to zero. However, these coefficients should not be zero due to the mentioned global water-mass exchange between Earth's surface and the atmosphere. To diminish this inconsistency, the $\Delta \mathrm{C}_{00}$ term from an atmospheric model could be added to GRACE (Chen et al. 2019; García-García et al. 2020). In this study, we add the $\Delta C_{00}$ term from ERA5 $P-E$ to $d W$. Errors in the estimate of $\Delta \mathrm{C}_{00}$ term propagate to the values of $d W$, but they do not affect to the estimates of $R, T$ and $G$ from Eq. 1, since the $\Delta \mathrm{C}_{00}$ term vanishes due to the residual estimate between $d W$ and $P-E$. In fact, adding $\Delta \mathrm{C}_{00}$ from $P-E$ to GRACE is numerically equivalent to set $\Delta \mathrm{C}_{00}$ of $P-E$ to zero as far as Eq. 1 is concerned. In addition, any mismodelling of the ocean basin ("container") volume change due to GIA would masquerade as WT variations. However, it is not critical as far as our non-secular analysis is concerned.

Note that $P-E$ units are $\mathrm{mm} / \mathrm{month}$, which multiplied by the surface of a cell grid in $\mathrm{m}^{2}$ yields volume transport units. GRACE units are $\mathrm{kg} / \mathrm{m}^{2}$ and the units for $d W$ are $(\mathrm{kg} /$ $\mathrm{m}^{2}$ )/month, which multiplied by the surface of a cell grid in $\mathrm{m}^{2}$ gives mass transport units. In order to make $P-E$ and $d W$ comparable, $d W$ units are transformed to volume transport units assuming a water density of $1000 \mathrm{~kg} / \mathrm{m}^{3}$ for fresh water and $1025 \mathrm{~kg} / \mathrm{m}^{3}$ for ocean water. In what follows, all results will represent volume transport and will be given in $\mathrm{km}^{3} /$ year. However, since volume transport through the Strait of Gibraltar in the literature is usually reported in $\mathrm{Sv}$ $\left(1 \mathrm{~Sv}=10^{6} \mathrm{~m}^{3} / \mathrm{s}\right)$, to ease the comparison with previous 
studies, the estimates of $G$ will be provided both in $\mathrm{km}^{3} /$ year and $\mathrm{Sv}$.

\subsection{Methods}

The annual and semiannual components of the WT time series have been estimated by applying a least-squares fitting to the model

$C_{t}=p_{0}+p_{1} \cdot t+A_{a} \cos \left(\omega_{a} \cdot t-\phi_{a}\right)+A_{s a} \cos \left(\omega_{s a} \cdot t-\phi_{s a}\right)$,

where $t$ represents time, $C_{t}$ the value of the time series of interest at time $t,(\omega, A, \Phi)=$ (frequency, amplitude, phase) and the suffix $a$ and $s a$ denotes annual and semiannual terms, respectively. The obtained results are identical when a third cosine term is included to account for the 161-day signal due to the $\mathrm{S} 2$ aliasing in GRACE data.

The reported standard deviations (SD) and 95\% confidence intervals (CI) for the averages, trend and seasonal signals of the components of the WT, as well as for correlations have been evaluated using the stationary bootstrap scheme of Politis and Romano (1994) with the optimal block length selected according to Patton et al. (2009). Note that each time series comprises 208 observations and can be seen as the union of two evenly spaced time series (with 181 observations from June 2002 to June 2017, and 27 observations from June 2018 to September 2020) separated by a gap of 11 months. Since the stationary bootstrap assumes evenly spaced data, the distributions and the SD of the estimators of the quantities of interest were obtained by applying the bootstrap to the first series (of length 181). In all cases the distribution of the estimator was approximately normal and thus the corresponding 95\% CI can be obtained as the mean of the bootstrap estimates plus/minus $2 \mathrm{SD}$. In order to make full use of the data, in the calculation of $95 \% \mathrm{CI}$, averages of the bootstrap estimates based on the reduced series (with 181 observations), were replaced by the estimate of the quantity of interest based on the original time series (with 208 observations). In most of the cases the correction is minor. To simplify notation all the results in the paper are presented in the form: estimate $\pm \mathrm{SD}$. The implementation of the stationary bootstrap used here is very similar to the one used in García-García et al. (2020). The number of bootstrap replications was set to 2000. A more detailed description follows.

\subsubsection{SD and $\mathrm{Cl}$ for the mean, trend and seasonal signals}

For each time series corresponding to a certain component of the WT, the harmonic regression model in Eq. 2, with annual and semiannual component plus a linear trend, was fitted to the data (by least-squares). The bootstrap was applied to the residuals of the fitted harmonic regression (to meet the stationarity conditions required by the method). For each time series corresponding to a certain component of the WT, the stationary bootstrap produced 2000 samples of the residuals that were added back to the fitted harmonic regression yielding 2000 bootstrapped time series of the component of interest. For each of these 2000 bootstrapped time series the mean of the component was evaluated and a harmonic regression model with annual and semiannual component plus a linear trend was fitted to the data producing 2000 estimates of the mean, the trend and seasonal signals of the components. These estimates were used to compute the SD and the distributions of the estimators of the quantities of interest.

\subsubsection{SD and $\mathrm{Cl}$ for correlation}

In order to avoid spurious correlation, for a given pair of variables of interest trend and seasonal component should be removed before computing the correlation. This can be done in several ways. Here we used two different approaches:

Approach 1: For a given pair of variables of interest, the harmonic regression model in Eq. 2, with annual and semiannual component plus a linear trend, was fitted to the data (by least-squares) corresponding to each variable and the residuals of the harmonic regression were computed. This produces a bivariate series of residuals with no trend and no seasonality.

Approach 2: For a given pair of variables of interest, the climatology corresponding to each component of the bivariate time series is computed and subtracted from the original time series. Since the trend component is in general not statistically significant, this alternative approach also produces bivariate residuals with approximately no trend and no seasonality and is more robust since it does not require the seasonal component to be approximately sinusoidal.

In both cases, the bootstrap was applied to the bivariate series of residuals. For each bivariate time series corresponding to the given pair of variables of interest, the stationary bootstrap produced 2000 samples of bivariate residuals. For each of these 2000 bootstrapped bivariate series of residuals the Pearson correlation coefficient was computed and these estimates were used to obtain the SD and the distributions of the sample correlation coefficient. In this article we only present the results corresponding to the second approach since those obtained using the first approach are very similar. Since the second approach is based on time series where the seasonal component was removed, we refer to the corresponding results and correlations as "non-seasonal signals" in Sect. 3.3. 
In order to understand the relative importance of the seasonal signal in the coupling observed between pairs of variables, correlation between the original series (without removing trend and seasonality) was also computed (having in mind that sometimes this might correspond to spurious correlation). For that purpose, the 2000 samples of bivariate residuals from approach 2 were added back to the climatology of each variable yielding 2000 bootstrapped bivariate time series of the pair of variables of interest. For each of these 2000 bootstrapped bivariate series of residuals the Pearson correlation coefficient was computed and these estimates were used to obtain the SD and the distribution of the sample correlation coefficient. Again, very similar results (not shown) are obtained if residuals are evaluated using approach 1 and added back to the fitted harmonic regression models.
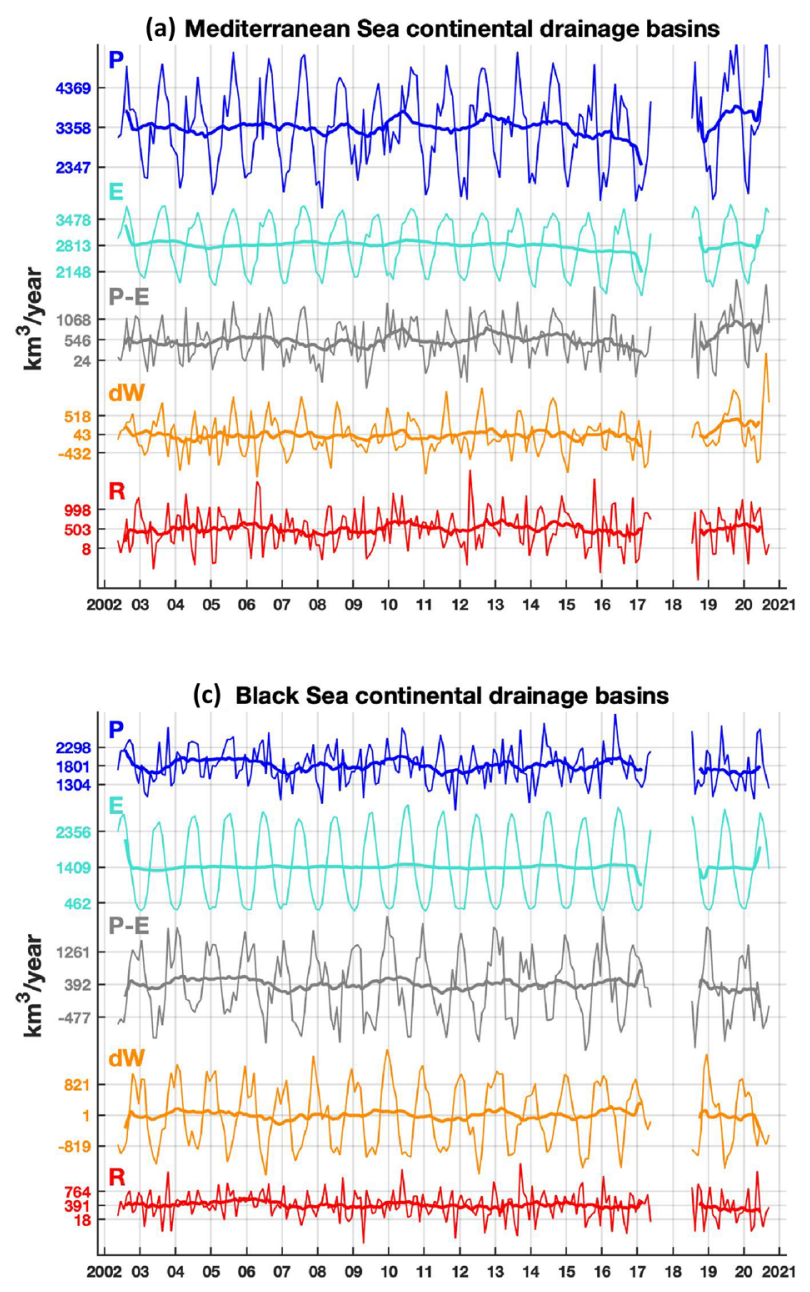

Fig. 2 Water transport (WT) components of Eq. 1 in the Mediterranean (first row) and Black seas (second row) and their drainage basins. First column: drainage basins; second column: ocean basins.

\section{Results}

In this section we present the mean estimates for each term of Eq. 1 applied to the drainage and oceanic basins of both Mediterranean and Black seas, as well as their temporal variability (Fig. 2). The results are discussed in the context of existing literature, and compared against estimates from previous studies. The seasonal and non-seasonal signals of water mass fluxes are also studied, and for the latter the influence of the North Atlantic Oscillation (NAO) on the temporal evolution of each term is explored.

\subsection{Mean values of WT}

A schematic representation of the mean water cycle in the Mediterranean-Black Sea system is depicted in Fig. 3.

(b) Mediterranean Sea

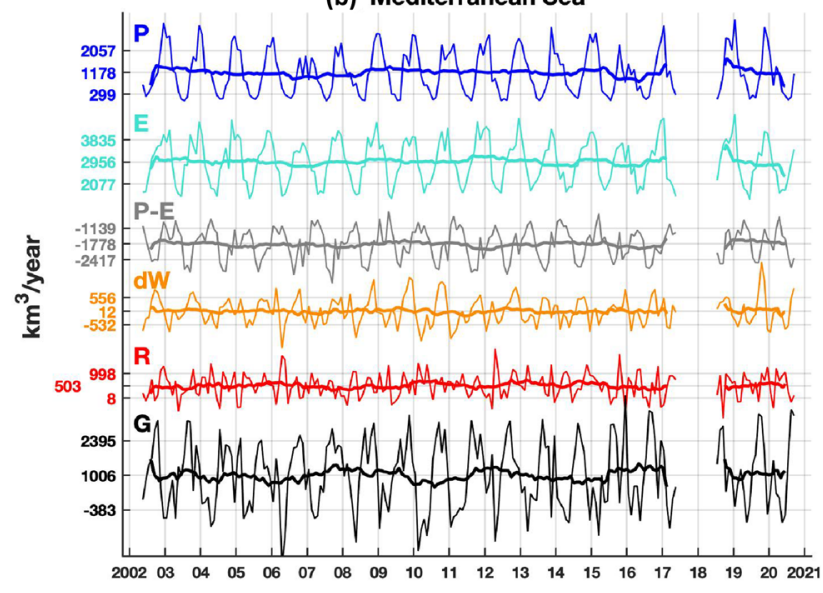

(d) Black Sea

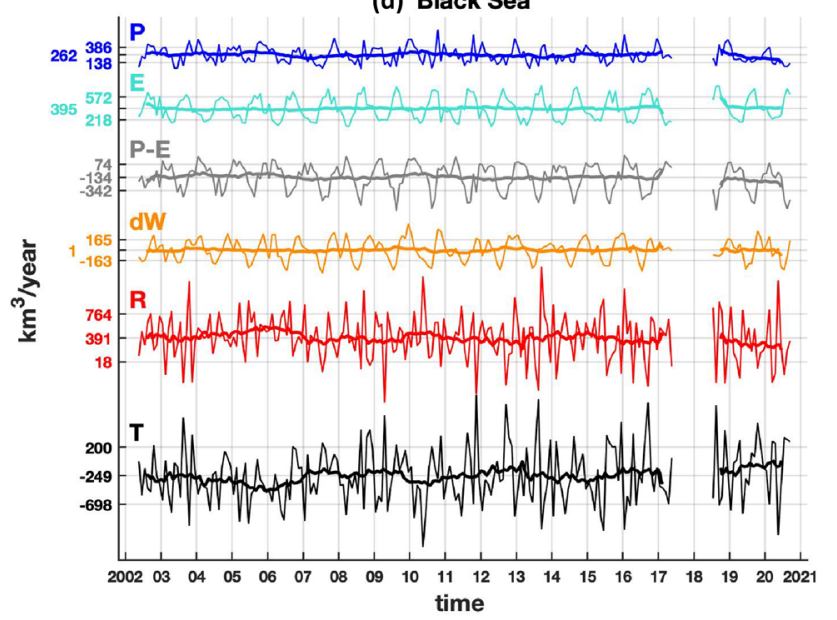

Thick lines depict the 12-month running mean. Positive $G$ and negative $T$ correspond to Mediterranean Sea inflows 
Fig. 3 Schematic representation of the mean water cycle in the Mediterranean Sea (reddish) and Black Sea (bluish) shown in Table 1. Units are $\mathrm{km}^{3} /$ year. Reported values are mean values, based on the original time series (with 208 observations) plus/minus the standard deviation estimated by stationary bootstrap based on the reduced series (with 181 observations)

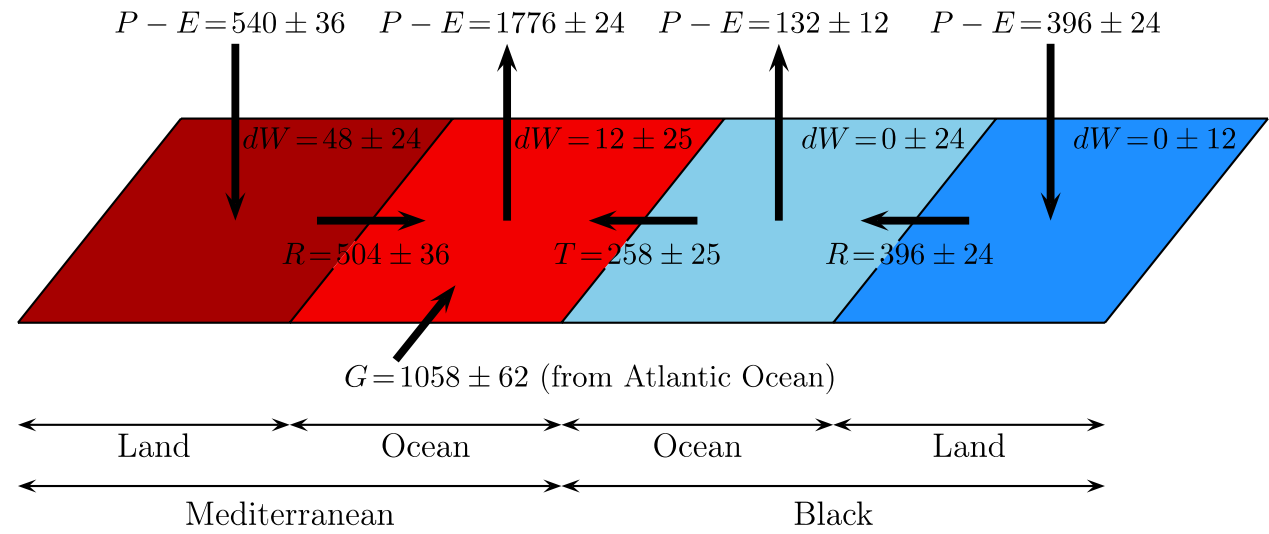

According to our estimates, the Black Sea drainage basins receive $378 \pm 31 \mathrm{~km}^{3} /$ year of net precipitation that produces a near identical amount of $R=391 \pm 12 \mathrm{~km}^{3} /$ year (Table 1 ). This value of $R$ is in the upper range of previous studies and agrees, within error estimates, with their averaged value, which is $360 \pm 43 \mathrm{~km}^{3} /$ year (Table 2). In the Black Sea, about one third of the water supplied by $R$ goes to the atmosphere via net evaporation, and the rest, $248 \pm 22 \mathrm{~km}^{3} /$ year, goes to the Mediterranean Sea through Turkish Straits ( $T$, Table 1$)$. This value is in the middle range of previous estimates and agrees, within error estimates, with their averaged value, which is $235 \pm 72 \mathrm{~km}^{3} /$ year (Table 3 ). The lowest estimates of $T$ based on in situ observations are $111 \pm 98$ $\mathrm{km}^{3} /$ year from September 2008 to February 2009 (Jarosz et al. 2011a, b), and $158 \mathrm{~km}^{3} /$ year from September 2008 to August 2009 (Jarosz et al. 2013). For these time periods our estimates are $198 \pm 133 \mathrm{~km}^{3} /$ year and $194 \pm 88 \mathrm{~km}^{3} /$ year, respectively, which are within the huge error estimate.

For the Mediterranean Sea our results confirm that the mean water budget remains approximately constant in time ( $d W=14 \pm 11 \mathrm{~km}^{3} /$ year), though it is characterized by a yearly important loss of water mass $\left(1787 \pm 23 \mathrm{~km}^{3} /\right.$ year $)$ through net evaporation, that is compensated by the total flow into the Mediterranean Sea. This inflow comes from: (i) continental runoff that contributes around a fourth of that budget $\left(502 \pm 27 \mathrm{~km}^{3} /\right.$ year); (ii) water transported from the Black Sea that accounts for half of the riverine contribution $\left(248 \pm 22 \mathrm{~km}^{3} /\right.$ year); and (iii) water coming from the Atlantic Ocean through the Strait of Gibraltar that accounts for the remaining $1020 \pm 56 \mathrm{~km}^{3} /$ year $(0.0323 \pm 0.0018 \mathrm{~Sv})$. Note that mean $G$ is four times mean $T$.

Again, the estimated fluxes are similar to those reported in the literature. First, our estimate of $R, 502 \pm 27 \mathrm{~km}^{3} /$ year, is in the upper range of previous studies for the Mediterranean Sea, and compatible, within error estimates, with their averaged value, which is $392 \pm 100 \mathrm{~km}^{3} /$ year (Table 2). However, this comparison should be interpreted with caution since the period of study seems to be relevant when estimating $R$. For example, the average of $R$ for studies covering a time window ending prior to 2002 is $329 \mathrm{~km}^{3} /$ year, while the corresponding value for studies ending after 2002 is greater than $500 \mathrm{~km}^{3} /$ year. Second, our estimate of $P-E$ in the Mediterranean Sea, $-1787 \pm 23 \mathrm{~km}^{3} /$ year, is larger in absolute value, than the $-1475 \mathrm{~km}^{3} /$ year reported by Boukthit and Barnier (2000). Finally, our estimate of $G$, $1020 \pm 56 \mathrm{~km}^{3} /$ year $(0.0323 \pm 0.0018 \mathrm{~Sv})$, is in the lower range of previous estimates and in agreement, within error estimates, with their averaged value, which is $1796 \pm 948$ $\mathrm{km}^{3} /$ year $(0.057 \pm 0.030 \mathrm{~Sv}$; Table 4$)$. The discrepancy between our estimate and reported values of $G$ from previous studies should be expected. For example, the larger value of $G\left(0.055 \mathrm{~Sv} ; 1734 \mathrm{~km}^{3} /\right.$ year) reported in GarcíaGarcía et al. (2010), is the result of differences not only in datasets and time periods, but also in the climatology used for $R$ (with a lower mean of $0.0095 \mathrm{~Sv} ; 300 \mathrm{~km}^{3} /$ year) and the neglection of $T$ in that study. These two terms ( $R$ and $T)$ accounted together for a Mediterranean input deficit of $0.0175 \mathrm{~Sv}$ (552 $\mathrm{km}^{3} /$ year) with respect to the present study, and such amount was erroneously attributed to $G$ in GarcíaGarcía et al. (2010). The same reasoning can be applied to the $0.057 \mathrm{~Sv}\left(1798 \mathrm{~km}^{3} /\right.$ year$)$ estimated by Boutov et al. (2014).

It is worth noting the regional dependence of $E$. Although the mean value of $E$ is similar in both Mediterranean Sea and associated drainage regions, the sea surface is less than half of land surface, which means that on sea $E$ per $\mathrm{m}^{2}$ is twice that on land. On the contrary, $E$ in Black Sea drainage regions is four times that in the Black Sea, but $E$ per $\mathrm{m}^{2}$ is similar in both regions.

\subsection{Seasonal signal of WT}

In the Mediterranean Sea fresh water inputs are lower than net evaporation. The water budget balance achieved thanks to the surplus of water from the Black Sea to the Mediterranean Sea via $T$, and the inflow from the North Atlantic Ocean to the Mediterranean Sea via $G$. However, the water mass imbalance is not compensated instantaneously in the 
Table 1 Mean, annual and semiannual signal of WT components in Fig. 2 estimated from Eq. 2

\begin{tabular}{|c|c|c|c|c|c|c|c|}
\hline & & $\begin{array}{l}\text { Mean } \pm S D, \mathrm{~km}^{3} / \\
\text { year }(95 \% \mathrm{CI})\end{array}$ & $\begin{array}{l}\text { Annual ampli- } \\
\text { tude } \pm \mathrm{SD}, \mathrm{km}^{3} / \\
\text { year }(95 \% \mathrm{CI})\end{array}$ & $\begin{array}{l}\text { Annual } \\
\text { phase } \pm \mathrm{SD}, \\
\text { degrees }(95 \% \mathrm{CI})\end{array}$ & $\begin{array}{l}\text { Semiannual ampli- } \\
\text { tude } \pm \mathrm{SD}, \mathrm{km}^{3} / \\
\text { year }(95 \% \mathrm{CI})\end{array}$ & $\begin{array}{l}\text { Semiannual } \\
\text { phase } \pm \mathrm{SD}, \\
\text { degrees }(95 \% \mathrm{CI})\end{array}$ & Annual peak \\
\hline \multirow{5}{*}{$\begin{array}{l}\text { Mediterranean Sea } \\
\text { drainage basins } \\
\left(5.34 \times 10^{6} \mathrm{~km}^{2}\right)\end{array}$} & $P$ & $\begin{array}{l}3376 \pm 39(3300 \\
3451)\end{array}$ & $\begin{array}{l}1185 \pm 54(1078, \\
1291)\end{array}$ & $218 \pm 3(213,223)$ & $\begin{array}{l}293 \pm 53(190, \\
397)\end{array}$ & $4 \pm 10(-15,24)$ & 9 Aug \\
\hline & $E$ & $\begin{array}{l}2826 \pm 18(2790 \\
2861)\end{array}$ & $\begin{array}{l}901 \pm 17(869) \\
934)\end{array}$ & $213 \pm 1(211,215)$ & $\begin{array}{c}136 \pm 12(113, \\
158)\end{array}$ & $10 \pm 5(0,19)$ & 4 Aug \\
\hline & $P-E$ & $\begin{array}{l}550 \pm 31(489 \\
611)\end{array}$ & $\begin{array}{l}298 \pm 44(210, \\
385)\end{array}$ & $233 \pm 9(215,252)$ & $159 \pm 45(70,247)$ & $\begin{array}{l}180 \pm 16(149 \\
211)\end{array}$ & 24 Aug \\
\hline & $d W$ & $49 \pm 12(25,72)$ & $\begin{array}{l}386 \pm 31(325 \\
447)\end{array}$ & $232 \pm 5(223,242)$ & $178 \pm 42(96,260)$ & $76 \pm 14(49,104)$ & 24 Aug \\
\hline & $R$ & $\begin{array}{l}502 \pm 27(449) \\
554)\end{array}$ & $88 \pm 38(13,164)$ & $\begin{array}{l}50 \pm 33(-15 \\
115)\end{array}$ & $\begin{array}{l}264 \pm 45(176 \\
352)\end{array}$ & $41 \pm 9(22,59)$ & $20 \mathrm{Feb}$ \\
\hline \multirow[t]{5}{*}{$\begin{array}{l}\text { Mediterranean Sea } \\
\left(2.43 \times 10^{6} \mathrm{~km}^{2}\right)\end{array}$} & $P$ & $\begin{array}{l}1164 \pm 30(1105 \\
1223)\end{array}$ & $\begin{array}{l}1099 \pm 42(1017 \\
1181)\end{array}$ & $356 \pm 2(352,360)$ & $143 \pm 41(64,223)$ & $103 \pm 22(61,145)$ & $27 \mathrm{Dec}$ \\
\hline & $E$ & $\begin{array}{l}2951 \pm 26(2900 \\
3003)\end{array}$ & $\begin{array}{l}1121 \pm 38(1046 \\
1195)\end{array}$ & $319 \pm 2(316,323)$ & $\begin{array}{l}188 \pm 37(116 \\
261)\end{array}$ & $55 \pm 11(33,77)$ & 20 Nov \\
\hline & $P-E$ & $\begin{array}{l}-1787 \pm 23 \\
\quad(-1832,-1742)\end{array}$ & $\begin{array}{l}696 \pm 32(633 \\
759)\end{array}$ & $69 \pm 3(64,75)$ & $\begin{array}{l}303 \pm 34(237 \\
370)\end{array}$ & $76 \pm 7(61,90)$ & $11 \mathrm{Mar}$ \\
\hline & $d W$ & $14 \pm 11(-7,34)$ & $\begin{array}{l}495 \pm 40(418 \\
573)\end{array}$ & $285 \pm 5(275,294)$ & $\begin{array}{l}229 \pm 51(129 \\
328)\end{array}$ & $16 \pm 16(-16,47)$ & $16 \mathrm{Oct}$ \\
\hline & $G+T$ & $\begin{array}{l}1268 \pm 40(1190 \\
1345)\end{array}$ & $\begin{array}{l}1193 \pm 75(1045 \\
1340)\end{array}$ & $262 \pm 4(255,269)$ & $\begin{array}{l}397 \pm 86(229 \\
565)\end{array}$ & $83 \pm 14(56,110)$ & 23 Sep \\
\hline \multirow{5}{*}{$\begin{array}{l}\text { Black Sea drain- } \\
\text { age basins } \\
\left(2.42 \times 10^{6} \mathrm{~km}^{2}\right)\end{array}$} & $P$ & $\begin{array}{c}1804 \pm 33(1739 \\
1869)\end{array}$ & $\begin{array}{l}259 \pm 45(170, \\
348)\end{array}$ & $\begin{array}{l}167 \pm 11(146 \\
188)\end{array}$ & $\begin{array}{l}190 \pm 44(104 \\
276)\end{array}$ & $136 \pm 19(98,173)$ & 19 Jun \\
\hline & $E$ & $\begin{array}{l}1426 \pm 8(1410 \\
1442)\end{array}$ & $\begin{array}{l}1318 \pm 12(1295 \\
1341)\end{array}$ & $177 \pm 1(176,178)$ & $\begin{array}{l}165 \pm 10(145, \\
186)\end{array}$ & $158 \pm 4(151,165)$ & 29 Jun \\
\hline & $P-E$ & $\begin{array}{l}378 \pm 31(317 \\
439)\end{array}$ & $\begin{array}{l}1064 \pm 44(978 \\
1150)\end{array}$ & $360 \pm 2(355,364)$ & $73 \pm 37(0,146)$ & $76 \pm 35(7,145)$ & $31 \mathrm{Dec}$ \\
\hline & $d W$ & $\begin{array}{c}-13 \pm 26 \\
(-64,39)\end{array}$ & $\begin{array}{l}1053 \pm 37(982 \\
1125)\end{array}$ & $358 \pm 2(354,362)$ & $69 \pm 33(5,134)$ & $64 \pm 34(-2,131)$ & $29 \mathrm{Dec}$ \\
\hline & $R$ & $\begin{array}{l}391 \pm 12(368 \\
414)\end{array}$ & $38 \pm 21(-3,79)$ & $73 \pm 32(9,136)$ & $15 \pm 19(-22,52)$ & $145 \pm 52(43,246)$ & 15 Mar \\
\hline \multirow[t]{5}{*}{$\begin{array}{l}\text { Black Sea } \\
\quad\left(0.45 \times \cdot 10^{6} \mathrm{~km}^{2}\right)\end{array}$} & $P$ & $260 \pm 6(249,272)$ & $108 \pm 9(90,125)$ & $345 \pm 5(335,354)$ & $2 \pm 7(-12,16)$ & $\begin{array}{l}62 \pm 48(-33 \\
157)\end{array}$ & $16 \mathrm{Dec}$ \\
\hline & $E$ & $398 \pm 4(390,405)$ & $217 \pm 6(205,230)$ & $255 \pm 2(252,258)$ & $69 \pm 6(57,81)$ & $82 \pm 6(71,93)$ & $15 \mathrm{Sep}$ \\
\hline & $P-E$ & $\begin{array}{l}-137 \pm 7(-151 \\
-123)\end{array}$ & $\begin{array}{l}242 \pm 10(222 \\
263)\end{array}$ & $48 \pm 2(44,53)$ & $71 \pm 10(51,91)$ & $81 \pm 9(64,99)$ & $18 \mathrm{Feb}$ \\
\hline & $d W$ & $-1 \pm 5(-10,8)$ & $\begin{array}{l}173 \pm 10(154 \\
192)\end{array}$ & $348 \pm 3(342,354)$ & $91 \pm 11(70,112)$ & $30 \pm 6(17,43)$ & $19 \mathrm{Dec}$ \\
\hline & $T$ & $\begin{array}{l}-248 \pm 22(-291 \\
-205)\end{array}$ & $\begin{array}{l}249 \pm 32(186 \\
312)\end{array}$ & $270 \pm 7(256,284)$ & $86 \pm 35(18,154)$ & $158 \pm 36(87,229)$ & 1 Oct \\
\hline Gibraltar flux & $G$ & $\begin{array}{l}1020 \pm 56(910 \\
1129)\end{array}$ & $\begin{array}{c}1440 \pm 90(1264 \\
1615)\end{array}$ & $263 \pm 3(257,270)$ & $\begin{array}{l}427 \pm 89(253 \\
601)\end{array}$ & $94 \pm 15(65,123)$ & $24 \mathrm{Sep}$ \\
\hline
\end{tabular}

Units are $\mathrm{km}^{3} /$ year for mean values and amplitudes, and degrees for phases. In each cell is reported: (i) the point estimate (based on the original time series) plus/minus the standard deviation (SD; estimated by bootstrap based on the reduced series, that is from 181 observations); (ii) The 95\% confidence interval, CI, computed has the point estimate plus/minus 2 SD. Regional surface areas are estimated with our grid resolution (see Fig. 1) and slightly differs from figures in the main text. Negative $T$ means a flux from the Black Sea to the Mediterranean Sea, and positive $G$ means a flux from the North Atlantic Ocean to the Mediterranean Sea. For the conversion of mass transport to volume transport, water density is fixed to $1000 \mathrm{~kg} / \mathrm{m}^{3}$ for fresh water and $1025 \mathrm{~kg} / \mathrm{m}^{3}$ for sea water

Mediterranean nor in the Black seas, and a climatological signal arise in all WT components and in water mass budgets. To analyze such climatology, an average year of each WT component is estimated averaging the signal of all Januarys, all Februarys, and so on. Figure 4 shows the average year or climatology for all WT components displayed in Fig. 2. 
Table 2 Runoff from continents to Mediterranean and Black seas as estimated by previous studies

\begin{tabular}{|c|c|c|c|c|}
\hline & Specifications & Period & Black Sea & Mediterranean Sea \\
\hline Ünlüata et al. (1990) & Historical data & - & 352 & - \\
\hline Boukthir and Barnier (2000) & Historical data & 1979-1993 & - & 347 \\
\hline Stanev et al. (2000) & In situ observations & 1992-1997 & 318 & - \\
\hline Stanev and Peneva (2002) & In situ observations & 1993-1997 & 340 & - \\
\hline Mariotti et al. (2002) & Historical data & - & - & 255 \\
\hline Struglia et al. (2004) & Historical data & - & - & $255-327$ \\
\hline Kara et al. (2008) & In situ observations & - & 287 & - \\
\hline \multirow[t]{2}{*}{ Ludwig et al. (2009) } & \multirow[t]{2}{*}{ Historical and modelled data } & $1960-1969$ & 396 & 387 \\
\hline & & $1991-2000$ & 403 & 328 \\
\hline Bouraoui et al. (2010) & From atmospheric data (no Nile) & $1980-2000$ & - & 308 \\
\hline Poulos (2011) & Historical data & - & 395 & 550 \\
\hline aus der Beek et al. (2012) & WaterGAP3 model & 2002-2009 & 406 & 518 \\
\hline Volkov and Landerer 2015 & Historical and reconstructed data & 1979-2010 & 302 & - \\
\hline \multirow[t]{4}{*}{ Jordà et al. 2017} & \multirow[t]{4}{*}{ Historical and modelled data } & $1960-1969$ & 375 & 392 \\
\hline & & $1991-2000$ & 382 & 328 \\
\hline & & 1980-2010 & - & $500 \pm 25$ \\
\hline & & $2005-2010$ & - & $500 \pm 25$ \\
\hline Literature summary & Mean \pm SD of these values (excluding this study) & - & $360 \pm 43$ & $392 \pm 100$ \\
\hline This study & GRACE and ERA5 atmospheric model & $\begin{array}{c}06 / 2002-06 / 2017 \text { and } \\
06 / 2018-09 / 2020\end{array}$ & $396 \pm 24$ & $504 \pm 36$ \\
\hline
\end{tabular}

Units are $\mathrm{km}^{3} /$ year

Regarding the Black Sea drainage basin, $P-E$ shows a clear annual cycle, mainly driven by $E$. The Pearson correlation between the $P-E$ and $E$ original time series is $-0.85 \pm 0.03$, while there is no significant correlation between $P-E$ and $P$ (Fig. 4c). The climatology of $P-E$ shows a maximum in January of $1473 \pm 94 \mathrm{~km}^{3} /$ year and a minimum in July of $-697 \pm 90 \mathrm{~km}^{3} /$ year (Fig. $4 \mathrm{c}$ ). The climatology of $d W$ mimics that from $P-E$, and their original time series show a correlation coefficient of $0.90 \pm 0.02$, meaning that the water budget variability is driven by $P-E$ (and $E$ ). On the other hand, $P$ and $R$ show a similar intra-annual variability (correlation coefficient of the original time series shown in Fig. 2 c is $0.57 \pm 0.09$ ), meaning that $R$ variability is mainly driven by $P$.

In the Mediterranean catchment region, the situation is somewhat different, since $P-E$ reaches two local maxima (Fig. 4a). The first one $\left(700 \pm 95 \mathrm{~km}^{3} /\right.$ year) is in April, and contributes to an annual maximum of $982 \pm 108 \mathrm{~km}^{3} /$ year for $R$. The surplus comes from stored water, since $d W$ shows a minimum in the same month of $-283 \pm 77 \mathrm{~km}^{3} /$ year. The second maximum of $P-E\left(1156 \pm 105 \mathrm{~km}^{3} /\right.$ year $)$ is in August and produces an annual maximum of $720 \pm 115 \mathrm{~km}^{3} /$ year for $d W$. This means that the excess of water in spring mainly runs away via runoff, unlike the excess of water in summer when $2 / 3$ of it is stored in land.

In the Black Sea, $P$ slightly exceeds $E$ from January to April (Fig. 4d). The month-to-month variability of $T$ is mainly driven by $R$ inflow. The correlation coefficient between the $T$ and $R$ original time series is $-0.91 \pm 0.02$. The correlation is negative since $R$ is always positive and negative values of $T$ indicate a flow from Black Sea to the Mediterranean Sea. During the first half of the year, riverine inputs to the Black Sea directly flow to the Mediterranean Sea at a mean rate of $448 \pm 35 \mathrm{~km}^{3} /$ year $(428 \pm 32$ $\mathrm{km}^{3} /$ year if July is included). During the second half of the year, the intra-annual variability of $T$ is still driven by $R$, but the mean value of $T$ is reduced to one tenth, mainly due to a great increase of $E$ (maxima in August and September) and changes in the water budget (maxima of $d W$ from October to December). In August and November, $T$ even reverses, bringing water from the Mediterranean to the Black Sea at a mean rate of $185 \pm 63 \mathrm{~km}^{3} /$ year, which compensates the minimum contributions of $R$ (Fig. $4 \mathrm{~d}$ ). This relationship between $R$ and $T$ would explain the lack of contribution of $R$ to sea level variability in the Black Sea (Volkov and Landerer 2015), and it agrees with the role of $P-E$ as the main driver of sea level variation in the Black Sea (Tsimplis et al. 2004). The reversal of $T$ has also been related to windinduced mass transport in the region (Stanev et al. 2000; Jarosz et al. 2011a, b).

In the Mediterranean Sea, there is an excess of $E$ over $P$ throughout the year (Fig. 4b). It produces a deficit of water mass that is balanced by the $R, T$ and $G$ inflows, although not instantaneously since there exists a delay in the response 
Table 3 Turkish Straits flux $(T)$ as estimated by previous studies

\begin{tabular}{|c|c|c|c|c|c|c|c|}
\hline & \multirow[t]{2}{*}{ Specifications } & \multirow[t]{2}{*}{ Period } & \multicolumn{3}{|l|}{ Net flux } & \multirow{2}{*}{$\begin{array}{l}\text { Med. input } \\
\text { Sv (km³/year) }\end{array}$} & \multirow{2}{*}{$\begin{array}{l}\text { Med. output } \\
\mathrm{Sv}\left(\mathrm{km}^{3} / \text { year }\right)\end{array}$} \\
\hline & & & $\begin{array}{l}\text { Mean, } \mathrm{Sv}\left(\mathrm{km}^{3} /\right. \\
\text { year) }\end{array}$ & $\begin{array}{l}\text { Annual amplitude, } \\
\mathrm{Sv}\left(\mathrm{km}^{3} / \text { year }\right)\end{array}$ & Annual phase, $\left(^{\circ}\right)$ & & \\
\hline $\begin{array}{l}\text { Ünlüata et al. } \\
\text { (1990) }\end{array}$ & $\begin{array}{l}\text { In situ observa- } \\
\text { tions; } \\
R \text { from observa- } \\
\quad \text { tions }\end{array}$ & 1986-1990 & $0.0095(300)$ & - & - & $0.0194(612)$ & $0.0099(312)$ \\
\hline $\begin{array}{l}\text { Beşiktepe et al. } \\
\text { (1994) }\end{array}$ & $\begin{array}{l}\text { In situ observa- } \\
\text { tions; } \\
\text { Salinity/hydro- } \\
\text { logic budget; } \\
R \text { from literature }\end{array}$ & 1986-1992 & $0.0095(300)$ & - & - & $0.0386(1218)$ & $0.0291(918)$ \\
\hline $\begin{array}{l}\text { Özsoy and } \\
\text { Ünlüata (1997) }\end{array}$ & $\begin{array}{l}\text { In situ observa- } \\
\text { tions; } \\
\text { Salinity/hydro- } \\
\text { logic budget; } \\
R \text { from literature }\end{array}$ & 1987-1993 & $0.0095(300)$ & - & - & $0.0374(1180)$ & $0.0279(880)$ \\
\hline $\begin{array}{l}\text { Stanev et al. } \\
\text { (2000) }\end{array}$ & $\begin{array}{l}\text { Altimetry/hydro- } \\
\text { logic budget; } \\
R \text { from observa- } \\
\text { tions }\end{array}$ & 1992-1997 & $0.0079(248)$ & - & - & - & - \\
\hline $\begin{array}{l}\text { Tugrul et al. } \\
\text { (2002) }\end{array}$ & $\begin{array}{l}\text { In situ observa- } \\
\text { tions; } \\
R \text { from literature }\end{array}$ & 1986-1999 & $0.0102(321)$ & - & - & $0.0422(1331)$ & $0.0320(1010)$ \\
\hline $\begin{array}{l}\text { Stanev and Peneva } \\
\text { (2002) }\end{array}$ & $\begin{array}{l}\text { Hydrologic } \\
\text { Budget; } \\
R \text { from observa- } \\
\text { tions }\end{array}$ & 1993-1997 & 0.0065 (205) & - & - & - & - \\
\hline $\begin{array}{l}\text { Kanarska and } \\
\text { Maderich } \\
\text { (2008) }\end{array}$ & $\begin{array}{l}\text { Ocean model; } \\
R \text { not considered }\end{array}$ & - & $0.0088(278)$ & - & - & $0.0388(1224)$ & $0.0300(946)$ \\
\hline Kara et al. (2008) & $\begin{array}{l}\text { Ocean model; } \\
R \text { from observa- } \\
\text { tions }\end{array}$ & - & $0.0069(217)$ & - & - & - & - \\
\hline $\begin{array}{l}\text { Jarosz et al. } \\
(2011 \mathrm{a}, \mathrm{b})\end{array}$ & $\begin{array}{l}\text { In situ observa- } \\
\text { tions; } \\
R \text { not considered }\end{array}$ & 09/2008-02/2009 & $\begin{array}{c}0.0035 \pm 0.0031 \\
(111 \pm 98)\end{array}$ & - & - & - & - \\
\hline \multirow[t]{2}{*}{$\begin{array}{l}\text { Fenoglio-Marc } \\
\text { et al. (2012) }\end{array}$} & $\begin{array}{l}\text { GRACE/Hydro- } \\
\text { logic Budget; } \\
R \text { from models }\end{array}$ & 08/2002-07/2008 & - & $\begin{array}{c}0.0130 \pm 0.0029 \\
(409 \pm 91)\end{array}$ & $260 \pm 5$ & - & - \\
\hline & $\begin{array}{l}\text { Altimetry/hydro- } \\
\text { logic budget; } \\
R \text { from models }\end{array}$ & 08/2002-07/2008 & - & $\begin{array}{c}0.0150 \pm 0.0022 \\
(474 \pm 71)\end{array}$ & $271 \pm 6$ & - & - \\
\hline $\begin{array}{l}\text { Jarosz et al. } \\
\text { (2013) }\end{array}$ & $\begin{array}{l}\text { In situ observa- } \\
\text { tions; } \\
R \text { not considered }\end{array}$ & 09/2008-08/2009 & $0.0050(158)$ & - & - & $0.0367(1157)$ & 0.0317 (999) \\
\hline $\begin{array}{l}\text { Volkov and Lan- } \\
\text { derer (2015) }\end{array}$ & $\begin{array}{l}\text { Altimetry/hydro- } \\
\text { logic budget; } \\
R \text { from historical } \\
\text { data }\end{array}$ & 1992-2010 & $0.0048(150)$ & - & - & - & - \\
\hline $\begin{array}{l}\text { Literature sum- } \\
\text { mary }\end{array}$ & $\begin{array}{l}\text { Mean } \pm \text { SD of } \\
\text { these values } \\
\text { (excluding this } \\
\text { study) }\end{array}$ & & $\begin{array}{c}0.0075 \pm 0.0023 \\
(235 \pm 72)\end{array}$ & - & - & $\begin{array}{c}0.0355 \pm 0.0081 \\
\quad(1120 \pm 256)\end{array}$ & $\begin{array}{c}0.0267 \pm 0.0084 \\
\quad(844 \pm 265)\end{array}$ \\
\hline This study & $\begin{array}{l}\text { GRACE and } \\
\text { ERA5 atmos- } \\
\text { pheric model; } \\
\text { Indirect estimate } \\
\text { of } R\end{array}$ & $\begin{array}{l}06 / 2002-06 / 2017 \\
\text { and 06/2018- } \\
09 / 2020\end{array}$ & $\begin{array}{l}0.0079 \pm 0.0007 \\
(248 \pm 22)\end{array}$ & $\begin{array}{c}0.008 \pm 0.003 \\
(249 \pm 32)\end{array}$ & $270 \pm 18$ & - & - \\
\hline
\end{tabular}

Instead of using GRACE data, some studies estimate sea water mass variability from altimetric measurements corrected for steric effects. In situ measurements are based on current and CTD (Conductivity-Temperature-Depth) observations. Positive net fluxes are Mediterranean inflows 
Table 4 Strait of Gibraltar flux $(G)$ as estimated by previous studies

\begin{tabular}{|c|c|c|c|c|c|c|c|}
\hline & \multirow[t]{2}{*}{ Specifications } & \multirow[t]{2}{*}{ Period } & \multicolumn{3}{|l|}{ Net flux (Sv) } & \multirow{2}{*}{$\begin{array}{l}\text { Med. input } \\
\text { Mean (Sv) }\end{array}$} & \multirow{2}{*}{$\begin{array}{l}\text { Med. output } \\
\text { Mean (Sv) }\end{array}$} \\
\hline & & & Mean (Sv) & $\begin{array}{l}\text { Annual ampli- } \\
\text { tude (Sv) }\end{array}$ & Annual phase $\left({ }^{\circ}\right)$ & & \\
\hline $\begin{array}{l}\text { Bryden and } \\
\text { Kinder (1991) }\end{array}$ & $\begin{array}{l}\text { Ocean model; } \\
R \text { not considered }\end{array}$ & - & 0.04 & - & - & 0.92 & 0.88 \\
\hline $\begin{array}{l}\text { Bryden et al. } \\
\text { (1994) }\end{array}$ & $\begin{array}{l}\text { Hydrologic/Salin- } \\
\text { ity budget; } \\
\text { In situ observa- } \\
\text { tions; } \\
R \text { not considered }\end{array}$ & 10/1985-10/1986 & 0.04 & - & - & 0.72 & 0.68 \\
\hline $\begin{array}{l}\text { Bouktnir and } \\
\text { Barnier (2000) }\end{array}$ & $\begin{array}{l}\text { Hydrologic } \\
\text { budget; } \\
R \text { from historical } \\
\quad \text { data }\end{array}$ & 1979-1993 & 0.031 & - & - & 0.771 & 0.740 \\
\hline $\begin{array}{l}\text { Tsimplis and } \\
\text { Bryden (2000) }\end{array}$ & $\begin{array}{l}\text { In situ observa- } \\
\text { tions; } \\
R \text { not considered }\end{array}$ & 04/1997-04/1998 & 0.11 & - & - & 0.78 & 0.67 \\
\hline $\begin{array}{l}\text { García Lafuente } \\
\text { et al. (2000) }\end{array}$ & $\begin{array}{l}\text { In situ observa- } \\
\text { tions; } \\
R \text { not considered }\end{array}$ & 10/1995-04/1996 & 0.05 & - & - & 0.92 & 0.87 \\
\hline $\begin{array}{l}\text { Baschek et al. } \\
\text { (2001) }\end{array}$ & $\begin{array}{l}\text { In situ observa- } \\
\text { tions; } \\
R \text { not considered }\end{array}$ & 10/1994-04/1997 & 0.05 & - & - & $0.81 \pm 0.07$ & $0.76 \pm 0.07$ \\
\hline Candela (2001) & $\begin{array}{l}\text { In situ observa- } \\
\text { tions; } \\
R \text { not considered }\end{array}$ & 10/1994-10-1996 & 0.04 & - & - & 1.01 & 0.97 \\
\hline $\begin{array}{l}\text { García Lafuente } \\
\text { et al. (2002) }\end{array}$ & $\begin{array}{l}\text { In situ observa- } \\
\text { tions; } \\
R \text { not considered }\end{array}$ & 10/1995-05/1998 & $0.14 \pm 0.07$ & $0.077 \pm 0.044$ & $234 \pm 33$ & $0.99 \pm 0.06$ & $0.84 \pm 0.04$ \\
\hline $\begin{array}{l}\text { Mariotti et al. } \\
(2002)\end{array}$ & $\begin{array}{l}\text { Hydrologic } \\
\text { budget; } \\
R \text { from historical } \\
\text { data ( } 76 \% \text { of } \\
\text { catchment area) }\end{array}$ & 1979-1993 & 0.039 & - & - & - & - \\
\hline $\begin{array}{l}\text { Brandt et al. } \\
\text { (2004) }\end{array}$ & $\begin{array}{l}\text { Ocean model; } \\
R \text { not considered }\end{array}$ & - & 0.027 & - & - & 0.621 & 0.594 \\
\hline $\begin{array}{l}\text { García et al. } \\
\text { (2006) }\end{array}$ & $\begin{array}{l}\text { GRACE/Hydro- } \\
\text { logic budget; } \\
R \text { not considered } \\
T \text { not considered }\end{array}$ & 09/2002-07/2004 & - & 0.016 & 263 & - & - \\
\hline $\begin{array}{l}\text { Vargas et al. } \\
\text { (2006) }\end{array}$ & $\begin{array}{l}\text { In situ observa- } \\
\text { tions; } \\
R \text { not considered }\end{array}$ & 10/1995-05/1996 & 0.1 & - & - & 0.9 & 0.8 \\
\hline $\begin{array}{l}\text { García-García } \\
\text { et al. (2010) }\end{array}$ & $\begin{array}{l}\text { GRACE/Hydro- } \\
\text { logic budget; } \\
R \text { from historical } \\
\text { data; } \\
T \text { not considered }\end{array}$ & 09/2002-03/2009 & 0.055 & $0.039 \pm 0.008$ & $253 \pm 13$ & - & - \\
\hline $\begin{array}{l}\text { Soto-Navarro } \\
\text { et al. (2010) }\end{array}$ & $\begin{array}{l}\text { Altimetry/Hydro- } \\
\text { logic budget; } \\
\text { In situ observa- } \\
\text { tions; } \\
R \text { from historical } \\
\text { data }\end{array}$ & 10/2004-01/2009 & $0.038 \pm 0.007$ & $0.042 \pm 0.018$ & September & $0.81 \pm 0.06$ & $0.78 \pm 0.05$ \\
\hline
\end{tabular}


Table 4 (continued)

\begin{tabular}{|c|c|c|c|c|c|c|c|}
\hline & \multirow[t]{2}{*}{ Specifications } & \multirow[t]{2}{*}{ Period } & \multicolumn{3}{|l|}{ Net flux (Sv) } & \multirow{2}{*}{$\begin{array}{l}\text { Med. input } \\
\text { Mean (Sv) }\end{array}$} & \multirow{2}{*}{$\begin{array}{l}\text { Med. output } \\
\text { Mean (Sv) }\end{array}$} \\
\hline & & & Mean (Sv) & $\begin{array}{l}\text { Annual ampli- } \\
\text { tude (Sv) }\end{array}$ & Annual phase $\left({ }^{\circ}\right)$ & & \\
\hline \multirow[t]{2}{*}{$\begin{array}{l}\text { Fenoglio-Marc } \\
\text { et al. (2012) }\end{array}$} & $\begin{array}{l}\text { GRACE/Hydro- } \\
\text { logic budget; } \\
R \text { from models }\end{array}$ & 08/2002-07/2008 & - & $0.050 \pm 0.011$ & $271 \pm 5$ & - & - \\
\hline & $\begin{array}{l}\text { Altimetry/Hydro- } \\
\text { logic Budget; } \\
R \text { from models }\end{array}$ & 08/2002-07/2008 & - & $0.051 \pm 0.010$ & $264 \pm 5$ & - & - \\
\hline $\begin{array}{l}\text { Boutov et al. } \\
\text { (2014) }\end{array}$ & $\begin{array}{l}\text { Ocean model; } \\
R \text { from literature }\end{array}$ & 1989-2009 & $0.057 \pm 0.009$ & - & - & $0.825 \pm 0.016$ & $0.768 \pm 0.017$ \\
\hline \multirow[t]{2}{*}{ Jordà et al. (2017) } & \multirow{2}{*}{$\begin{array}{l}\text { Hydrologic } \\
\text { budget; } \\
R \text { from historical } \\
\text { and modeled } \\
\text { data }\end{array}$} & 1980-2010 & $0.040 \pm 0.016$ & - & - & - & - \\
\hline & & 2005-2010 & $0.048 \pm 0.016$ & - & - & - & - \\
\hline $\begin{array}{l}\text { Sánchez-Leal } \\
\text { et al. (2017) }\end{array}$ & $\begin{array}{l}\text { Current and CTD } \\
\text { observations; } \\
R \text { not considered }\end{array}$ & 1971-2017 & $0.05 \pm 0.07$ & - & - & $1.04 \pm 0.11$ & $1.00 \pm 0.10$ \\
\hline $\begin{array}{l}\text { Sánchez-Román } \\
\text { et al. (2018) }\end{array}$ & $\begin{array}{l}\text { Ocean model; } \\
R \text { from historical } \\
\quad \text { data }\end{array}$ & 01/1958-11/1967 & $0.07 \pm 0.011$ & - & - & $0.68 \pm 0.09$ & $0.61 \pm 0.06$ \\
\hline $\begin{array}{l}\text { Literature sum- } \\
\text { mary }\end{array}$ & $\begin{array}{l}\text { Mean } \pm \text { SD of } \\
\text { these values } \\
\text { (excluding this } \\
\text { study) }\end{array}$ & & $0.057 \pm 0.030$ & $0.046 \pm 0.020$ & $257 \pm 14$ & $0.843 \pm 0.13$ & $0.783 \pm 0.12$ \\
\hline This study & $\begin{array}{l}\text { GRACE and } \\
\text { ERA5 atmos- } \\
\text { pheric model; } \\
\text { Indirect estimate } \\
\text { of } R\end{array}$ & $\begin{array}{l}06 / 2002-06 / 2017 \\
\text { and } 06 / 2018- \\
09 / 2020\end{array}$ & $0.0323 \pm 0.0018$ & $0.0457 \pm 0.0029$ & $263 \pm 7$ & - & - \\
\hline
\end{tabular}

Instead of using GRACE data, some studies estimate sea water mass variability from altimetry measurements corrected for steric effects. In situ measurements are current and/or CTD (Conductivity-Temperature-Depth) observations. Positive net fluxes are Mediterranean inflows

of the water budget. Although with different amplitude, the component $G$ mirrors the variability of $P-E$, yielding a correlation coefficient between the original time series of $-0.77 \pm 0.05$. $G$ shows an oceanic water mass inflow from June to February of $1913 \pm 107 \mathrm{~km}^{3} / \mathrm{year}$, with a maximum flux of $2726 \pm 113 \mathrm{~km}^{3} /$ year in August and September. However, in April and May, $G$ reverses showing a mean net outflow of $407 \pm 140 \mathrm{~km}^{3} /$ year from the Mediterranean Sea to the Atlantic Ocean, which is very close to the $414 \pm 77 \mathrm{~km}^{3}$ / year Black Sea inflow during those months. This reversal of $G$ is favoured by the maximum of $R$ and the minimum of $E$.

Regarding the annual and semiannual signals of the inflow/outflow fluxes, we have found that the annual amplitude of $T$ is $249 \pm 32 \mathrm{~km}^{3} /$ year and peaks on October 1 , which agrees, within error estimates, with a similar study performed by Fenoglio-Marc et al. (2012) with GRACE data. They estimated $T$ for the period 08/2002-07/2008 from previous versions of GRACE and atmospheric data, and $R$ was derived from a hydrological model, reporting an annual signal of $T$ peaking on September 27 ( $-T$ peaks on
March 28) with an amplitude of $409 \pm 91 \mathrm{~km}^{3} /$ year. Our estimate for the same period produces an even smaller annual amplitude of $204 \pm 44 \mathrm{~km}^{3} /$ year and peaks on October 11 (phase is 280 that corresponds to October 7) with a SD of 13 days. Similarly, our estimate of the annual signal of $G$ peaks on September $24\left(263^{\circ} \pm 7^{\circ}\right)$ with an annual amplitude of $1513 \pm 182 \mathrm{~km}^{3} /$ year $(0.048 \pm 0.006 \mathrm{~Sv})$, which is within the middle range of previous estimates and agrees with their averaged value, $0.048 \pm 0.020 \mathrm{~Sv}$ (Table 4 ).

\subsection{Non-seasonal signal of WT}

The non-seasonal signal is obtained subtracting the climatology from the original signal. This way is more appropriated than fitting an annual sinusoid since the average year is not always sinusoidal in shape (Fig. 4). In general, $E$ shows very low non-seasonal variability, except in the Mediterranean Sea, where month-to-month variability is 3 times larger than in other regions (Fig. 5). In contrast, $P$ shows larger nonseasonal variability everywhere except in the Black Sea. 

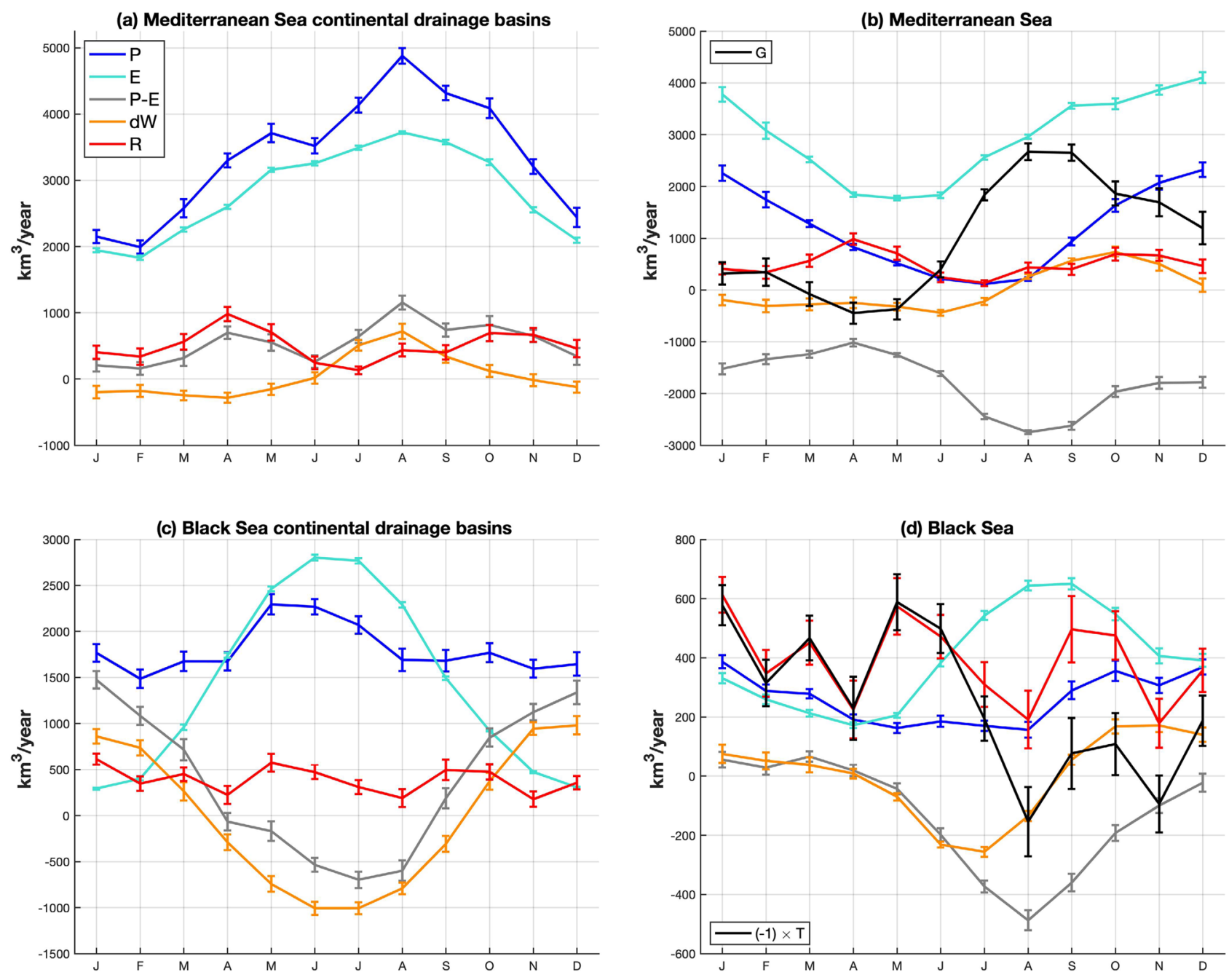

Fig. 4 Climatology (monthly averages) of signals shown in Fig. 2

In the Black Sea catchment region, the non-seasonal variability of $P$ is propagated to $P-E, d W$, and $R$. The Pearson correlation coefficients between $P$ and $P-E, R$, and $d W$ are $0.98 \pm 0.01,0.61 \pm 0.09$, and $0.57 \pm 0.09$, respectively (Fig. 6b). The correlation between $P-E$ and $E$ for non-seasonal time series is not statistically significant, which confirms that non-seasonal variability of $P-E$ is driven mainly by $P$. The inter-annual variability of $P-E$ is quite large. For example, in 2005, a maximum mean value of $P-E=600$ $\mathrm{km}^{3} /$ year produced a maximum $R=510 \mathrm{~km}^{3} /$ year, while in 2011, a minimum $P-E=153 \mathrm{~km}^{3} /$ year produced a minimum $R=326 \mathrm{~km}^{3} /$ year. Note that the excess of $R$ over $P-E$ in 2011 came from water extraction from land reserves, when $d W$ presented an anomalous deficit of $-173 \mathrm{~km}^{3} /$ year. On the other hand, the correlation between $R$ and $T$ increases in magnitude from $-0.91 \pm 0.02$ (original series in Fig. 2) to $-0.97 \pm 0.01$ for the non-seasonal signals in Fig. 7. This means that $R$ into the Black Sea goes almost simultaneously, or with a lag of less than a month, to the Mediterranean Sea. The maximum of $R$ in 2005 produced a maximum transport of water mass from the Black Sea to the Mediterranean Sea of $438 \mathrm{~km}^{3} /$ year. On the other hand, the minimum of $R$ in 2011 halved $T\left(212 \mathrm{~km}^{3} /\right.$ year $)$. The differences between $R$ and $T$ are due to variations of water mass in the Black Sea, meaning that $R$ is not the only factor driving $T$. Note that $T$ is also forced by sea level changes in the Aegean Sea, sea level pressure variations over the Black Sea, and by winds blowing near Turkish Straits (Ducet et al. 1999; Jarosz et al. 2011b; Volkov and Landerer 2015; Volkov et al. 2016). Finally, the inter-annual variability of $T$ has been reported in previous studies (Tsimplis et al. 2004; Peneva et al. 2001).

In the Mediterranean catchment region, the situation is similar. The non-seasonal variability of $P$ is propagated to $P-E$ and $R$, with which shows a correlation coefficient of $0.96 \pm 0.01$ and $0.64 \pm 0.09$, respectively (Fig. 6). The correlation of $P$ and $d W$ is still significant, although decreases 

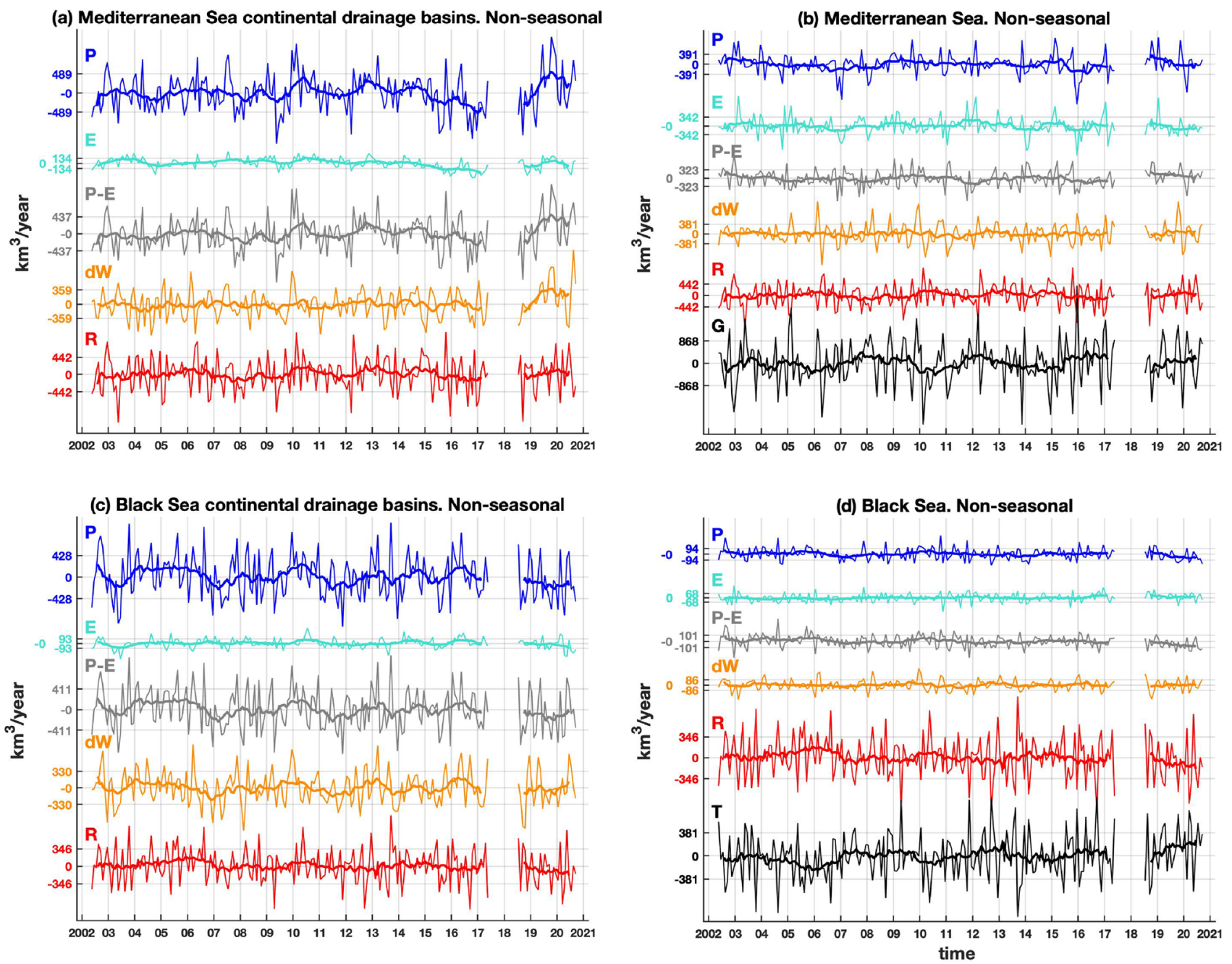

Fig. 5 Non-seasonal signal of WT components shown in Fig. 2

from $0.61 \pm 0.08$ (original time series, Fig. 2) to $0.38 \pm 0.11$ (non-seasonal time series). As in the Black Sea catchment region, the inter-annual variability of $P-E$ in the Mediterranean catchment region is also quite large. For example, in $2010, P-E$ reached a maximum of $736 \mathrm{~km}^{3} /$ year that produced a maximum $R=665 \mathrm{~km}^{3} /$ year, while in $2008, P-E$ reached a minimum of $432 \mathrm{~km}^{3} /$ year that produced a minimum $R=410 \mathrm{~km}^{3} /$ year. Once again, the differences between $R$ and $P-E$ are balanced by variations in water land reserves.

On the other hand, the correlation between $G$ and $P-E$ in the Mediterranean Sea decreases in magnitude from $-0.77 \pm 0.05$ for the original time series in Fig. 2 to $-0.41 \pm 0.12$ for the non-seasonal time series in Fig. 5 . Conversely, the correlation between $G$ and Mediterranean $R$ increases in magnitude from $-0.56 \pm 0.08$ for the original time series to $-0.78 \pm 0.05$ for the non-seasonal time series (Fig. 7). This may be interpreted as that $P-E$ drives the climatology of $G$, but $R$ is more important regarding the non-seasonal variability of $G$, which agrees with the fact that large unpredictable cyclones, especially in the Western Mediterranean, are accompanied by low-pressure systems. Altogether increases captured rainfall (and hence river runoff) and may rise Mediterranean sea level by means of the inverse barometer effect (Lionello et al. 2019). This interpretation is supported by the significant correlation of $0.34 \pm 0.08$ and $-0.40 \pm 0.06$ observed between the non-seasonal signals of the mean sea level pressure (from ERA5), and (i) $G$, and (ii) Mediterranean $R$, respectively. This interpretation is not in contradiction with the reported influence of winds near the Strait of Gibraltar on $G$ (Landerer and Volkov 2013), since water mass blown by winds must overcome the hydraulic pressure produced by riverine waters. The larger $R$, the lower $G$ as the sea level gradient decreases between both sides of the Strait of Gibraltar. Then, the maximum $R$ in 2010 reduced the inflow from the Atlantic Ocean to the 
Fig. 6 Correlation coefficients among all the WT components in Fig. 2 (a), and Fig. 5 (b). White squares represent correlations that are not statistically significant (the corresponding 95\% CI contains the zero)
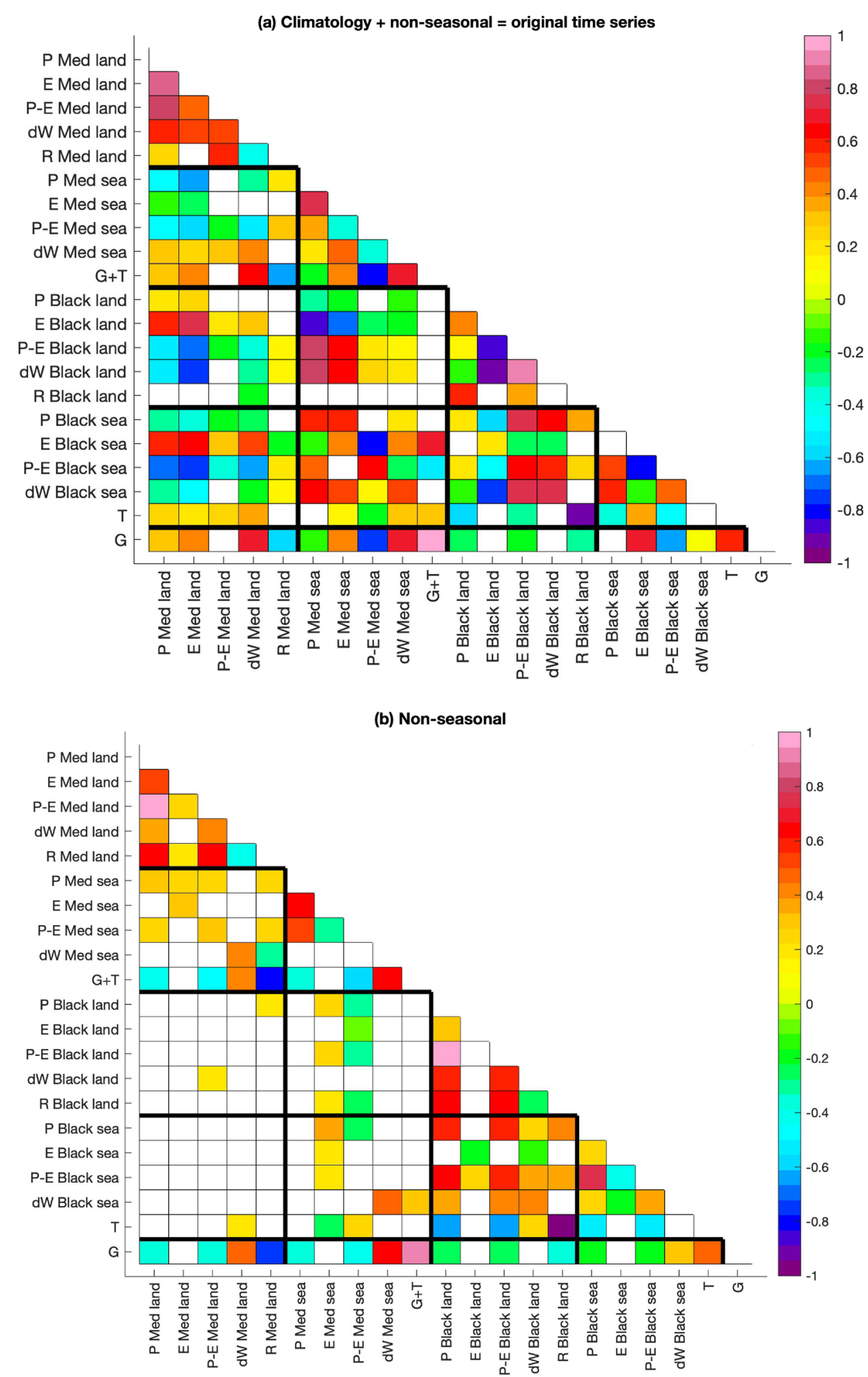

(b) Non-seasonal

Mediterranean Sea to $706 \mathrm{~km}^{3} /$ year $(0.0224 \mathrm{~Sv})$, while the minimum of $R$ in 2008 increased such transport to 1262 $\mathrm{km}^{3} /$ year $(0.0400 \mathrm{~Sv})$. Note that $G$ in 2008 almost doubled the value in 2010 . However, a strong inter-annual variability of $G$ has been previously reported in the literature, e.g.
Boutov et al. (2014) provided estimates of $G=0.023 \mathrm{~Sv}$ in 1996 and $G=0.082 \mathrm{~Sv}$ in 2000 .

Linear trends have been estimated according to Eq. 2 . However, only four WT components showed a statistically significant linear trend (the 95\% confidence interval for 

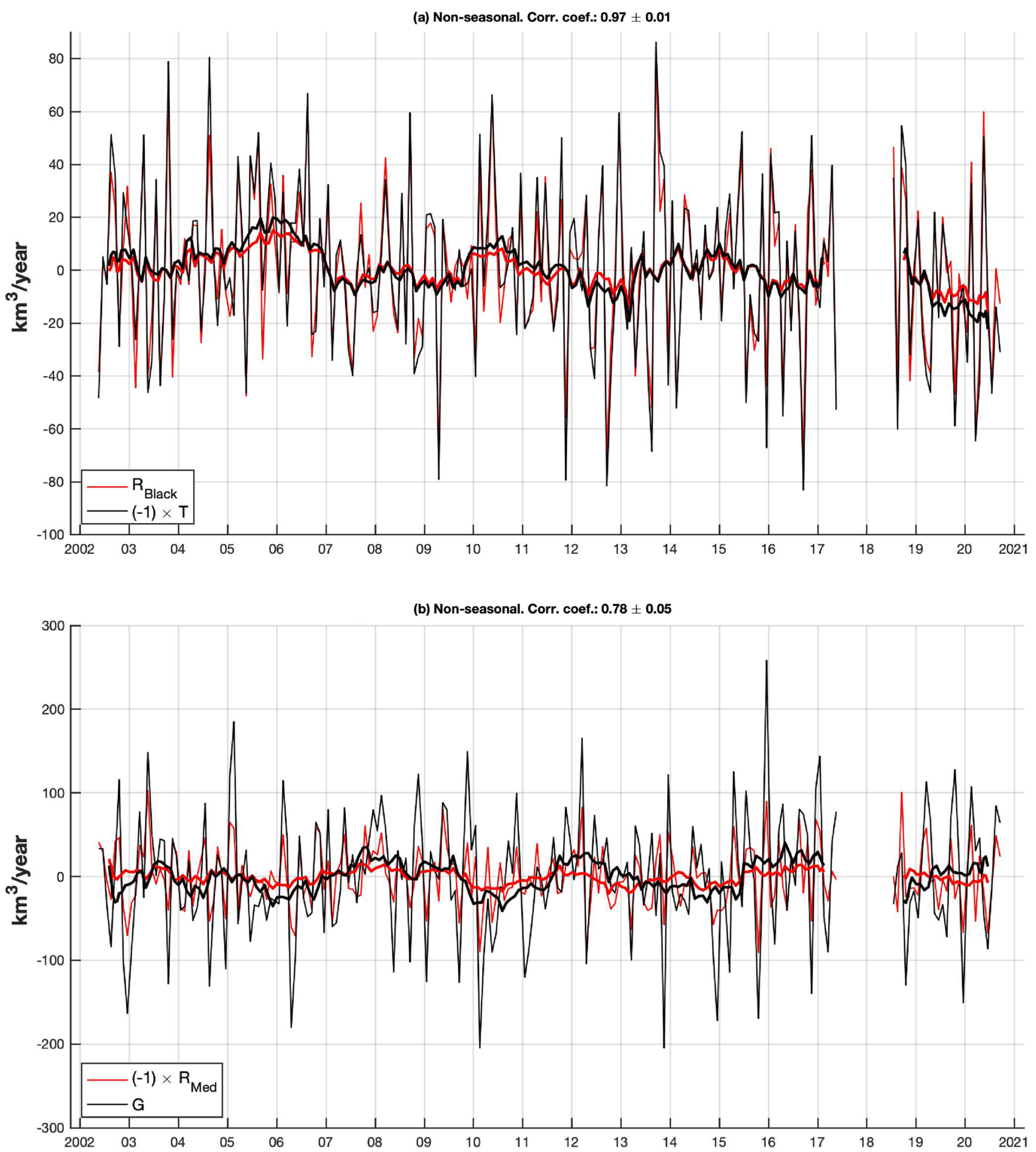

Fig. 7 Non-seasonal oceanic water exchange between the Mediterranean Sea and $\mathbf{a}$ the Black Sea $(T)$, and $\mathbf{b}$ the Atlantic Ocean $(G)$. Black curves are $\mathbf{a}-T$, and $\mathbf{b} G$; and red curves are a) $R$ in Black Sea, and $-R$ in the Mediterranean Sea. As $T$ is multiplied by -1 , positive

the trend does not contain 0$): d W$ in the continental catchment region of the Mediterranean Sea, trend $=117 \pm 35$ $\mathrm{km}^{3} /$ year $^{2} ; R$ in the Black Sea, trend $=-84 \pm 36 \mathrm{~km}^{3} /$ (negative) values of black curves represent Mediterranean inflows (outflows). Note the negative signs in the depicted curves. Correlations between $R$ in the Black Sea and $T$, and between $R$ in the Mediterranean Sea and $G$ are both negatives

year ${ }^{2} ; P-E$ in the Black Sea, trend $=-48 \pm 18 \mathrm{~km}^{3} / \mathrm{year}^{2}$; and $T$, trend $=129 \pm 58.5 \mathrm{~km}^{3} /$ year $^{2}$. As negative values of $T$ represent water transport from the Black Sea into the 
Mediterranean Sea, the reported positive linear trend of $T$ represents a reduction of mass transport.

\subsection{Influence of NAO on WT}

The NAO is a climate atmospheric index characterized by sea level air pressure differences between the high-pressure system located over the Azores islands and the low-pressure system over Iceland. The NAO oscillates between positive and negative phases, which have a great influence in weather conditions on Europe and the Mediterranean Sea (Hurrell 1995), as well as in sea level (e.g., Vigo et al. 2011, Ozgenc Akoy 2017). However, we did not find any significant Pearson correlation between the NAO index estimated by NOAA (https://www.cpc.ncep.noaa.gov/products/precip/CWlink/ pna/nao.shtml), and the non-seasonal time series in Fig. 5. The situation is different when the NAO index is averaged over winter months (December-March). In that case, the NAO influence is revealed. A positive (negative) NAO phase produces drier (wetter) than average conditions in the region (Hurrell 1995). The correlation between winter NAO and (i) the annual averages, and (ii) the winter averages of signals in Fig. 5 have been estimated. The reported SD have been obtained applying ordinary bootstrap to the bivariate series of annual/winter averages. It should be noted that, in this case, the estimated sampling distribution of the correlation coefficients is often skewed. In the first case, only five components show a statistically significant correlation: $-0.62 \pm 0.15$ for $E$ on Mediterranean catchment region; $-0.44 \pm 0.18$ and $-0.49 \pm 0.16$ for $R$ and $P-E$ in Black Sea; $0.50 \pm 0.15$ for $T$; and $0.51 \pm 0.18$ for $G$. Similarly, in the second case only four winter averaged components show a statistically significant correlation: $-0.65 \pm 0.23$, and $-0.55 \pm 0.12$, for $P$ and $E$ on Mediterranean catchment region; $-0.49 \pm 0.16$ and $-0.54 \pm 0.20$ for $E$ and $d W$ on Black Sea catchment region. Note that only the correlation of $E$ on Mediterranean catchment region is significant for both annual and winter averages.

The correlation of the annual averages of $R$ in the Black Sea is close to the -0.47 similarly estimated by Stanev and Peneva (2002) for the period 1923-1997. Among the 5 largest rivers discharging into the Black Sea (Danube, Dnepr, Dnestr, Don, and Kuban), the Danube is the most important, accounting for $60 \%$ of the mean $R$ in the Black Sea, and its catchment region is the most influenced by NAO. In fact, if the $R$ in the Black Sea is estimated without accounting for the Danube, the correlation with NAO becomes not significant.

Mariotti et al. (2002) found significant correlations between NAO and both annual and winter averages of both $P$ and $P-E$ in a box (latitude, longitude $=\left[25^{\circ} \mathrm{N}, 52^{\circ} \mathrm{N}\right]$, $\left.\left[10^{\circ} \mathrm{W}, 40^{\circ} \mathrm{E}\right]\right)$ covering both the Mediterranean and Black seas. In our case, we only found significant correlation between NAO and the components $P$ (Mediterranean catchment region) and $P-E$ (Black Sea) when winter averages are considered. Besides, we found a significant correlation between NAO and $E$ on Mediterranean catchment region for both annual and winter averages. However, there are important differences with respect to our region (see Fig. 1) that may explain the distinct correlation coefficients. For example, they included continental regions corresponding to the Atlantic catchment region, but not the Nile River basin, which extension is more than half of the total Mediterranean catchment region and it is out of the NAO area of influence (Struglia et al. 2004).

It is known that the NAO influences the large-scale sea level pressure patterns over the Mediterranean and Black seas. In particular, NAO modulates the winds near: (1) the Strait of Gibraltar, which influences the non-seasonal water mass transport and the Mediterranean sea level variations (Landerer and Volkov 2013); (2) the Turkish Straits, which influence the water mass transport and the Black Sea level variations (Volkov and Landerer 2015; Jarosz et al. 2011a; $2011 b)$. Then, the connection between NAO and the annual averages of $G$ and $T$ can be explained by these processes.

\section{Discussion and conclusions}

In this work we present an estimate of the hydrological cycle of the Mediterranean-Black Sea system, for the period 2002-2020, based on atmospheric reanalysis and time-variable gravity data and the water budget equation (Eq. 1). In particular, we provide a time variable estimate of $G$, which is crucial to understand the dynamics of the Mediterranean Sea (Malanotte-Rizzoli et al. 2014). We report a mean net flux of $G=0.0323 \pm 0.0018 \mathrm{~Sv}(1020 \pm 56$ $\mathrm{km}^{3} /$ year), which accounts for $58 \%$ of the water lost by net evaporation in the Mediterranean Sea. In addition, $G$ shows a clear annual cycle, increasing to $0.0844 \pm 0.0035 \mathrm{~Sv}$ $\left(2660 \pm 111 \mathrm{~km}^{3} /\right.$ year $)$ in August $/$ September, and reversing to $-0.0129 \pm 0.0044 \mathrm{~Sv}$ in $\left(-407 \pm 140 \mathrm{~km}^{3} /\right.$ year $)$ April/May, when a net WT from the Mediterranean Sea to the Atlantic Ocean takes place. On top of the climatology, $G$ shows a significant inter-annual variability with annual means ranging from $0.0224\left(706 \pm 56 \mathrm{~km}^{3} /\right.$ year $)$ to $0.0400 \mathrm{~Sv}\left(1262 \pm 56 \mathrm{~km}^{3} /\right.$ year $)$ during the studied period.

Previous studies have attempted to estimate the components of WT in the Mediterranean and/or Black Sea using Eq. 1, either assuming that $d W$ is null (Ünlüata et al. 1990; Bryden and Kinder 1991; Boukthir and Barnier 2000), or estimating $d W$ from steric-corrected altimetry (Stanev et al. 2000; Soto-Navarro et al. 2010; Volkov and Landerer 2015) and from GRACE (García et al. 2006; García-García et al. 2010; Fenoglio-Marc et al. 2012). In all these approaches, the continental fresh water input $R$ has been estimated with 
climatologies obtained from historical runoff measurements, or from hydrological models (as listed in Tables 3 and 4). The main novelties of our approach are: (i) the combination of the latest versions of GRACE and ERA5 datasets to obtain more reliable estimates of the water cycle in the region; and (ii) the indirect monthly estimates of $R$ for the period of study. This represents a critical improvement due to the important differences in $R$ from year to year (a mean decrease of $\sim 15 \%$ and a mean increase of $\sim 30 \%$ of $R$ has been observed in some years in both Mediterranean and Black seas, respectively, though not always simultaneously). Consequently, years with above-average (low-average) $R$ in the Black Sea produced above-average (below-average) $T$, while years with above-average (below-average) $R$ in the Mediterranean produced below-average (above-average) $G$. This variability should be kept in mind when comparing estimates of $G$ and $T$ from studies performed in different periods. However, the indirect estimate of $R$ is not perfect. As GRACE missions cannot distinguish the signal at length scales below $300 \mathrm{~km}$, and the diameter of some river basins in the Mediterranean-Black Sea system are smaller than that distance, some errors are expected to arise. In particular, for certain months $R$ takes negative values (Fig. 4), which has no physical meaning.

Our climatology of $R$ in the Black Sea is quite different to that estimated by Volkov and Landerer (2015), where $R$ showed a more sinusoidal shape with maximum in April/ May and minimum in September/October. Their $R$ was estimated from a reconstruction of discharge measurements of the 5 largest rivers discharging into the Black Sea, and our $R$ is calculated using a larger continental area. We re-estimated $R$ using the 5 largest rivers as in Volkov and Landerer (2015) (not shown) and the signal was quite close to that shown in Fig. 4d which means that the continental area considered is not the source of the discrepancy between our and Volkov and Landerer's estimates. A possible explanation for this discrepancy may reside in the fact that our $R$ component includes surface running water out of the major rivers and underground water transport. In particular, the intra-annual signal of $R$, and so the lack of sinusoidal waveform, is mainly produced by the more irregular $P$ in the continental catchment region of the Black Sea (Figs. 4c and 6a). On the other hand, as $R$ drives the intra-annual variability of $T$, our climatology of $T$ shows a less clear annual cycle than that estimated by Peneva et al. (2001), although both show the maximum transport during the first half of the year, and the minimum during the second one. However, the shape of our climatology of $T$ is similar to that reported by Stanev et al. (2000). In any case, it should be highlighted that the methodologies and periods of study were different. For example, instead of GRACE data (not available prior to 2002), both Stanev et al. (2000) and Peneva et al. (2001) used altimetric measurements, whereas steric estimates from climatic heat fluxes between the Black Sea and the atmosphere came from ECMWF data and were combined with historical records of $R$ prior to the studied periods.

In the Mediterranean Sea, our climatology of $R$ is closer to two sinusoidal cycles (with one maximum in spring and another in autumn), than to one annual cycle with maximum in spring as reported in previous studies (Boukthir and Barnier 2000; Mariotti et al. 2002). However, as it happened in the Black Sea, those climatologies of $R$ are estimated from historical observations of rivers discharge. Then, differences may be produced by distinct periods of time or non-river continental discharges. Besides, in addition to winds near the Strait of Gibraltar (Landerer and Volkov 2013), we report that low-pressure systems over the Mediterranean Sea also influence the non-seasonal variability of $G$ (and of $R$ ).

An important feature of the here proposed methodology is that the water cycle of the Mediterranean-Black Sea system has been estimated using only two datasets, and these are expected to be available and periodically extended and updated for the scientific community in the coming years. In this regard, our approach offers the opportunity to continuously monitor the long-term variability of the water cycle in the region, which is important to understand the seasonal and the inter-annual variabilities, and their regional and global implications. Although in general the linear trends of WT components are not significant for the studied period, the inter-annual variability has been shown to be significant. Knowing such variability is not only important to better identify the physical mechanisms, but also at biological level, since, for example, the water transported through the Strait of Gibraltar conditions the exchange of nutrients. On the other hand, long time series would allow to detect possible variations in the seasonal signal that are expected as a consequence of the climate changes produced by the global warming (Held and Soden 2006; Huntington 2006; Greve et al. 2014).

Acknowledgements All data used in this study are publicly available and we thank all the organizations that provide them: ERA5 data provided by the Copernicus Climate Change Service Climate Data Store (CDS), https://cds.climate.copernicus.eu/cdsapp\#!/home; GRACE time-variable gravity data provided by CSR, University of Texas, http:// www2.csr.utexas.edu/grace; North Atlantic Oscillation (NAO) from NOAA Climate Prediction Center (CPC).

Funding Open Access funding provided thanks to the CRUE-CSIC agreement with Springer Nature.The work of DGG, MIV, and MT was partially supported by Spanish Project RTI2018-093874-B-100 funded by MCIN/AEI/10.13039/501100011033, and by Generalitat Valenciana grant number GVA-THINKINAZUL/2021/035. DGG and IV were partially supported by Grant PROMETEO/2021/030 (Generalitat Valenciana). JMS thanks the joint funding received from the Generalitat Valenciana and the European Social Fund under Grant APOSTD/2020/254 
Availability of data and material Not applicable.

Code availability Not applicable.

\section{Declarations}

Conflict of interest The authors declare that there is no conflict of interest.

Open Access This article is licensed under a Creative Commons Attribution 4.0 International License, which permits use, sharing, adaptation, distribution and reproduction in any medium or format, as long as you give appropriate credit to the original author(s) and the source, provide a link to the Creative Commons licence, and indicate if changes were made. The images or other third party material in this article are included in the article's Creative Commons licence, unless indicated otherwise in a credit line to the material. If material is not included in the article's Creative Commons licence and your intended use is not permitted by statutory regulation or exceeds the permitted use, you will need to obtain permission directly from the copyright holder. To view a copy of this licence, visit http://creativecommons.org/licenses/by/4.0/.

\section{References}

Artale V, Calmanti S, Malanotte-Rizzoli P, Pisacane G, Rupolo V et al (2006) The Atlantic and the Mediterranean Sea as connected systems. In: Lionello P, Malanotte-Rizzoli P, Boscolo R (eds) Developments in earth and environmental sciences, vol 4. Elsevier, Amsterdam, pp 283-323

aus der Beek T, Menzel L, Rietbroek R, Fenoglio-Marc L, Grayek S, Becker M, Kusche J, Stanev EV (2012) Modeling the water resources of the Black and Mediterranean Sea river basins and their impact on regional mass changes. J Geodyn 59-60:157-167. https://doi.org/10.1016/j.jog.2011.11.011

Baschek B, Send U, García-Lafuente J, Candela J (2001) Transport estimates in the Strait of Gibraltar with a tidal inverse model. J Geophys Res 106(C12):31033-31044. https://doi.org/10.1029/ 2000JC000458

Bergamasco A, Malanotte-Rizzoli P (2010) The circulation of the Mediterranean Sea: a historical review of experimental investigations. Adv Oceanogr Limnol 1(1):11-28. https://doi.org/10.1080/19475 721.2010 .491656

Beşiktepe ST, Sur Hİ, Emin Özsoy M, Latif A, Oğuz T, Ünlüata Ü (1994) The circulation and hydrography of the Marmara Sea. Prog Oceanogr 34(4):285-334. https://doi.org/10.1016/0079-6611(94) 90018-3

Boukthir M, Barnier B (2000) Seasonal and inter-annual variations in the surface freshwater flux in the Mediterranean Sea from the ECMWF re-analysis project. J Marine Syst 24(3):343-354. https://doi.org/10.1016/S0924-7963(99)00094-9

Bouraoui F, Grizzetti B, Aloe A (2010) Estimation of water fluxes into the Mediterranean Sea. J Geophys Res 115:D21116. https://doi. org/10.1029/2009JD013451

Boutov D, Peliz A, Miranda PMA, Soares PMM, Cardoso RM, Prieto L, Ruiz J, García-Lafuente J (2014) Inter-annual variability and long term predictability of exchanges through the Strait of Gibraltar. Glob Planet Change 114:23-37. https://doi.org/10.1016/j.glopl acha.2013.12.009

Brandt P, Rubino A, Sein DV, Baschek B, Izquierdo A, Backhaus JO (2004) Sea level variations in the Western Mediterranean studied by a numerical tidal model of the strait of gibraltar. J
Phys Oceanogr 34(2):433-443. https://doi.org/10.1175/15200485(2004)034\%3c0433:SLVITW\%3e2.0.CO;2

Bryden HL, Kinder TH (1991) Steady two-layer exchange through the Strait of Gibraltar. Deep Sea Res Part A Oceanogr Res Pap 38(Suppl 10):S445-S463. https://doi.org/10.1016/S01980149(12)80020-3

Bryden HL, Candela J, Kinder TH (1994) Exchange through the Strait of Gibraltar. Prog Oceanogr 33:201-248. https://doi.org/10.1016/ 0079-6611(94)90028-0

Candela J (2001) Mediterranean water and global circulation. In: Siedler G, Gould J, Church J (eds) Ocean circulation and climate observing and modelling the global ocean. Academic Press, p 715

Chao BF (2016) Caveats on the equivalent water thickness and surface mascon solutions derived from the GRACE satellite-observed time-variable gravity. J Geodesy 90:807-813. https://doi.org/10. 1007/s00190-016-0912-y

Cheng M, Ries J (2017) The unexpected signal in GRACE estimates of $\mathrm{C}_{20} \mathrm{C} 20$. J Geod 91:897-914. https://doi.org/10.1007/ s00190-016-0995-5

Chen J, Tapley B, Seo KW, Wilson C, Ries J (2019) Improved quantification of global mean ocean mass change using GRACE satellite gravimetry measurements. Geophys Res Lett 46:1398413991. https://doi.org/10.1029/2019GL085519

Collins M, Sutherland M, Bouwer L, Cheong SM, Frölicher T, Jacot Des Combes H, Koll Roxy M, Losada I, McInnes K, Ratter B, Rivera-Arriaga E, Susanto RD, Swingedouw D, Tibig L (2019) Extremes, abrupt changes and managing risk. In: Pörtner H-O, Roberts DC, Masson-Delmotte V, Zhai P, Tignor M, Poloczanska E, Mintenbeck K, Alegría A, Nicolai M, Okem A, Petzold J, Rama B, Weyer NM (eds) IPCC special report on the ocean and cryosphere in a changing climate. Intergovernmental Panel on Climate Change, Geneva, pp 589-656

Coste B, Le Corre P, Minas HJ (1988) Re-evaluation of the nutrient exchange in the Strait of Gibraltar. Deep-Sea Res 35:767-775

Ducet N, Le Traon PY, Gauzelin P (1999) Response of the Black Sea mean level to atmospheric pressure and wind forcing. J Mar Syst 22:311-327. https://doi.org/10.1016/S0924-7963(99)00072-X

Durack PJ, Wijffels SE, Matear RJ (2012) Ocean salinities reveal strong global water cycle intensification during 1950-2000. Science 336(6080):455-458. https://doi.org/10.1126/science. 1212222

Fenoglio-Marc L, Rietbroek R, Grayek S, Becker M, Kusche J, Stanev E (2012) Water mass variation in the Mediterranean and Black Seas. J Geodyn 59-60:168-182. https://doi.org/10. 1016/j.jog.2012.04.001

García-García D, Chao BF, Boy JP (2010) Steric and mass-induced sea level variations in the Mediterranean Sea revisited. J Geophys Res 115:C12016. https://doi.org/10.1029/2009JC005928

García D, Chao BF, Del Río J, Vigo I, García-Lafuente J (2006) On the steric and mass-induced contributions to the annual sea level variations in the Mediterranean Sea. J Geophys Res 111:C09030. https://doi.org/10.1029/2005JC002956

García-García D, Vigo MI, Trottini M (2020) Water transport among the world ocean basins within the water cycle. Earth Syst Dynam 11:1089-1106. https://doi.org/10.5194/esd-11-1089-2020

García-Lafuente J, Vargas JM, Plaza F, Sarhan T, Candela J, Bascheck B (2000) Tide at the eastern section of the Strait of Gibraltar. J Geophys Res Oceans 105(C6):14197-14213. https:// doi.org/10.1029/2000JC900007

Garcia-Lafuente J, Delgado J, Vargas JM, Vargas M, Plaza F, Sarhan $\mathrm{T}$ (2002) Low-frequency variability of the exchanged flows through the Strait of Gibraltar during CANIGO. Deep Sea Res Part II: Top Stud Oceanogr 49(19):4051-4067. https://doi.org/ 10.1016/S0967-0645(02)00142-X

Giorgi F (2006) Climate change hot-spots. Geophys Res Lett 33:L08707. https://doi.org/10.1029/2006GL025734 
Gómez F, González N, Echevarría F, García CM (2000) Distribution and fluxes of dissolved nutrients in the Strait of Gibraltar and its relationships to microphytoplankton biomass. Estuar Coast Shelf Sci 51:439-449. https://doi.org/10.1006/ecss.2000.0689

Greve P, Orlowsky B, Mueller B et al (2014) Global assessment of trends in wetting and drying over land. Nat Geosci 7:716-721. https://doi.org/10.1038/ngeo2247

Held IM, Soden BJ (2006) Robust responses of the hydrological cycle to global warming. J Clim 19:5686-5699. https://doi.org/ 10.1175/JCLI3990.1

Hersbach H, de Rosnay P, Bell B, Schepers D, Simmons A, Soci C, Abdalla S, Alonso-Balmaseda M, Balsamo G, Bechtold P, Berrisford P, Bidlot J-R, de Boisséson E, Bonavita M, Browne P, Buizza R, Dahlgren P, Dee D, Dragani R, Diamantakis M, Flemming J, Forbes R, Geer AJ, Haiden T, Hólm E, Haimberger L, Hogan R, Horányi A, Janiskova M, Laloyaux P, Lopez P, Munoz-Sabater J, Peubey C, Radu R, Richardson D, Thépaut J-N, Vitart F, Yang X, Zsótér E, Zuo H (2018) Operational global reanalysis: progress, future directions and synergies with NWP. ERA Report Series 27. https://doi.org/10.21957/tkic6g3wm

Huntington TG (2006) Evidence for intensification of the global water cycle: review and synthesis. J Hydrol 319:83-95. https:// doi.org/10.1016/j.jhydrol.2005.07.003

Hurrell JW (1995) Decadal trends in the North Atlantic Oscillation: regional temperatures and precipitation. Science 269:676-679. https://doi.org/10.1126/science.269.5224.676

Jarosz E, Teague WJ, Book JW, Besiktepe S (2011a) Observed volume fluxes in the bosphorus strait. Geophys Res Lett 38:L21608. https://doi.org/10.1029/2011GL049557

Jarosz E, Teague WJ, Book JW, Besiktepe S (2011b) On flow variability in the bosphorus strait. J Geophys Res 116:C08038. https://doi.org/10.1029/2010JC006861

Jordà G, Von Schuckmann K, Josey SA, Caniaux G, García-Lafuente J, Sammartino S, Özsoy E, Polcher J, Notarstefano G, Poulain PM, Adloff F, Salat J, Naranjo C, Schroeder K, Chiggiato J, Sannino G, Macías D (2017) The Mediterranean Sea heat and mass budgets: estimates, uncertainties and perspectives. Prog Oceanogr 156:174-208. https://doi.org/10.1016/j.pocean.2017.07.001

Jarosz E, Teague WJ, Book JW, Beşiktepe ŞT (2013) Observed volume fluxes and mixing in the Dardanelles Strait. J Geophys Res Oceans 118:5007-5021. https://doi.org/10.1002/jgrc.20396

Kanarska Y, Maderich V (2008) Modelling of seasonal exchange flows through the Dardanelles Strait. Estuar Coast Shelf Sci 79:449458. https://doi.org/10.1016/j.ecss.2008.04.019

Kara AB, Wallcraft AJ, Hulbert HE, Stanev EV (2008) Air-sea fluxes and river discharges in the Black Sea with a focus on the Danube and Bosphorus. J Mar Syst 74:74-95. https://doi.org/10.1016/j. jmarsys.2007.11.010

Landerer FW, Volkov DL (2013) The anatomy of recent large sea level fluctuations in the Mediterranean Sea. Geophys Res Lett. https:// doi.org/10.1002/grl.50140

Lionello P, Conte D, Reale M (2019) The effect of cyclones crossing the Mediterranean region on sea level anomalies on the Mediterranean Sea coast. Nat Hazards Earth Syst Sci 19:1541-1564. https:// doi.org/10.5194/nhess-19-1541-2019

Ludwig W, Dumont E, Meybeck M, Heussner S (2009) River discharges of water and nutrients to the Mediterranean and Black Sea: major drivers for ecosystem changes during past and future decades? Prog Oceanogr 80(3-4):199-217. https://doi.org/10. 1016/j.pocean.2009.02.001

Malanotte-Rizzoli P, Artale V, Borzelli-Eusebi GL, Brenner S et al (2014) Physical forcing and physical/biochemical variability of the Mediterranean Sea: a review of unresolved issues and directions for future research. Ocean Sci 10:281-322. https://doi.org/ 10.5194/os-10-281-2014
Mariotti A, Struglia MV, Zeng N, Lau KM (2002) The Hydrological Cycle in the Mediterranean Region and Implications for the Water Budget of the Mediterranean Sea. J Clim 15(13):1674-1690. https://doi.org/10.1175/1520-0442(2002)015\%3c1674:THCITM\% 3e2.0.CO;2

Markonis Y, Papalexiou SM, Martinkova M, Hanel M (2019) Assessment of water cycle intensification over land using a multisource global gridded precipitation dataset. J Geophys Res Atmos 124:11175-11187. https://doi.org/10.1029/2019JD030855

McGill DA (1953) (1961) A preliminary study of the oxygen and phosphate distribution in the Mediterranean Sea. Deep Sea Res 8:259-268. https://doi.org/10.1016/0146-6313(61)90027-2

Millot C, Taupier-Letage I (2005) Circulation in the Mediterranean Sea. In: Saliot A (ed) The Mediterranean Sea. Handbook of environmental chemistry, vol 5K. Springer, Berlin Heidelberg. https:// doi.org/10.1007/b107143

Oki T, Sud YC (1998) Design of total runoff integrating pathways (trip) - a global river channel network. Earth Interactions 2, Paper No. 1. https://doi.org/10.1175/1087-3562(1998)002<0001:DOTRI $\mathrm{P}>2.3 . \mathrm{CO} ; 2$

Ozgenc AA (2017) Investigation of sea level trends and the effect of the north atlantic oscillation (NAO) on the black sea and the eastern Mediterranean sea. Theor Appl Climatol 129:129-137. https:// doi.org/10.1007/s00704-016-1759-0

Özsoy E, Ünlüata Ü (1997) Oceanography of the Black Sea: a review of some recent results. Earth Sci Rev 42(4):231-272. https://doi. org/10.1016/S0012-8252(97)81859-4

Pascolini-Campbell M, Reager JT, Chandanpurkar HA et al (2021) A 10 per cent increase in global land evapotranspiration from 2003 to 2019. Nature 593:543-547. https://doi.org/10.1038/ s41586-021-03503-5

Patton A, Politis DN, White H (2009) Correction to "Automatic blocklength selection for the dependent bootstrap." Economet Rev 28:372-375. https://doi.org/10.1080/07474930802459016

Peltier WR, Argus DF, Drummond R (2018) Comment on "An assessment of the ICE-6G_C (VM5a) glacial isostatic adjustment model" by Purcell et al. J Geophys Res Solid Earth 123:20192028. https://doi.org/10.1002/2016JB013844

Peneva E, Stanev E, Belokopytov V, Le Traon PY (2001) Water transport in the Bosphorus Strait estimated from hydro-meteorological and altimeter data: Seasonal and decadal variability. J Mar Syst 31:21-33. https://doi.org/10.1016/S0924-7963(01)00044-6

Pérez-Asensio JN, Aguirre J, Schmiedl G, Civis J (2012) Impact of restriction of the Atlantic-Mediterranean gateway on the Mediterranean Outflow Water and eastern Atlantic circulation during the Messinian. Paleoceanography 27:PA3222. https://doi.org/10. 1029/2012PA002309

Politis DN, Romano JP (1994) The stationary bootstrap. J Am Stat Assoc 89:1303-1313. https://doi.org/10.1080/01621459.1994. 10476870

Poulos S (2011) An insight to the fluvial characteristics of the Mediterranean and Black Sea watersheds. In: Lambrakis N, Stournaras G, Katsanou K (eds) Advances in the research of aquatic environment. Environmental earth sciences. Springer, Berlin Heidelberg. https://doi.org/10.1007/978-3-642-19902-8_22

Reid JL (1979) On the contribution of the Mediterranean Sea outflow to the Norwegian-Greenland Sea. Deep Sea Res 26:1199-1223. https://doi.org/10.1016/0198-0149(79)90064-5

Sánchez-Leal RF, Bellanco MJ, Fernández-Salas LM, García-Lafuente J, Gasser-Rubinat M, González-Pola C, Hernández-Molina JF, Pelegrí JL, Peliz A, Relvas P, Roque D, Ruiz-Villarreal M, Sammartino S, Sánchez-Garrido JC (2017) The Mediterranean overflow in the Gulf of Cadiz: a rugged journey. Sci Adv 3(11):eaao0609. https://doi.org/10.1126/sciadv.aao0609 
Sanchez-Roman A, Jorda G, Sannino G, Gomis D (2018) Modelling study of transformations of the exchange flows along the Strait of Gibraltar. Ocean Sci 14(6):1547-1566. https://doi.org/10.5194/ os-14-1547-2018

Save H (2019) CSR GRACE RL06 mascon solutions, Texas Data Repository Dataverse, V1. https://doi.org/10.18738/T8/UN91VR

Save H, Bettadpur S, Tapley BD (2016) High resolution CSR GRACE RL05 mascons. J Geophys Res Solid Earth. https://doi.org/10. 1002/2016JB013007

Soto-Navarro JF, Criado-Aldeanueva J, García-Lafuente J, SánchezRomán A (2010) Estimation of the Atlantic inflow through the Strait of Gibraltar from climatological and in situ data. J Geophys Res 115:C10023. https://doi.org/10.1029/2010JC006302

Stanev E, Peneva E (2002) Regional sea level response to global climatic change: Black Sea examples. Glob Planet Change 32:33-47. https://doi.org/10.1016/S0921-8181(01)00148-5

Stanev EV, Le Traon PY, Peneva EL (2000) Sea level variations and their dependency on meteorological and hydrological forcing: analysis of altimeter and surface data for the Black Sea. J Geophys Res 105(C7):17203-17216. https://doi.org/10.1029/1999J C900318

Struglia MV, Mariotti A, Filograsso A (2004) River discharge into the Mediterranean Sea: climatology and aspects of the observed variability. J Clim 17:4740-4751. https://doi.org/10.1175/JCLI-3225.1

Sun Y, Riva R, Ditmar P (2016) Optimizing estimates of annual variations and trends in geocenter motion and $\mathrm{J}_{2}$ from a combination of GRACE data and geophysical models. J Geophys Res Solid Earth 121:8352-8370. https://doi.org/10.1002/2016JB013073

Swenson S, Chambers D, Wahr J (2008) Estimating geocenter variations from a combination of GRACE and ocean model output. J Geophys Res 113:B08410. https://doi.org/10.1029/2007JB005338

Tsimplis MN, Josey SA, Rixen M, Stanev EV (2004) On the forcing of sea level in the Black Sea. J Geophys Res 109:C08015. https:// doi.org/10.1029/2003JC002185
Tugrul S, Besiktepe T, Salihoglu I (2002) Nutrient exchange fluxes between the Aegean and Black Seas through the Marmara Sea, Mediterranean. Mar Sci 3(1):33-42. https://doi.org/10.12681/ mms.256

Ünlüata U, Oguz T, Latif MA, Özsoy E (1990) On the physical oceanography of the Turkish Straits. In: Pratt G (ed) The physical oceanography of Sea Straits NATO ASI Ser, Ser C. Kluwer Academic Publishing, Norwell, pp 25-60

Vargas JM, García-Lafuente J, Candela J, Sánchez AJ (2006) Fortnightly and monthly variability of the exchange through the Strait of Gibraltar. Prog Oceanogr 70(2-4):466-485. https://doi.org/10. 1016/j.pocean.2006.07.001

Vellinga M, Wood RA (2002) Global climate impacts of a collapse of the Atlantic thermohaline circulation. Clim Change 54:251-267. https://doi.org/10.1023/A:1016168827653

Vigo MI, Sanchez-Reales JM, Trottini M, Chao BF (2011) Mediterranean sea level variations: analysis of the satellite altimetric data, 1992-2008. J Geodyn 52(3-4):271-278. https://doi.org/10.1016/j. jog.2011.02.002

Volkov DL, Landerer FW (2015) Internal and external forcing of sea level variability in the Black Sea. Clim Dyn 45:2633-2646. https://doi.org/10.1007/s00382-015-2498-0

Volkov DL, Johns WE, Belonenko TV (2016) Dynamic response of the Black Sea elevation to intraseasonal fluctuations of the Mediterranean sea level. Geophys Res Lett 43:283-290. https://doi.org/ 10.1002/2015GL066876

Publisher's Note Springer Nature remains neutral with regard to jurisdictional claims in published maps and institutional affiliations. 